\title{
Falls from height: analysis of 114 cases
}

\author{
Tomi Zlatar** (D), Eliane Maria Gorga Lago (D), Willames de Albuquerque Soares ${ }^{\mathrm{a}}$ (D), \\ João dos Santos Baptista ${ }^{\mathrm{b}}$ (D), Béda Barkokébas Junior ${ }^{\mathrm{a}}$ (D) \\ aEscola Politecnica, Universidade de Pernambuco, Recife, PE, Brasil

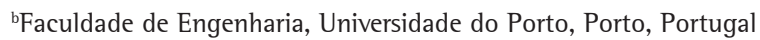 \\ *tomi.zlatar@gmail.com
}

\begin{abstract}
Paper aims: To study fall-accident cases in order to analyze the commonly missing or not adequately applied risk management measures (RMM) and its consequences depending on falling height.

Originality: First study to analyze failed RMM for preventing falls from height.

Research method: The study reviewed court cases published by the journal "Safety \& Health Practitioner". NIOSH recommendations were used to define RMM to apply to this study.

Main findings: Finally, in 98\% of analyzed cases, the fall from height was a result of several non-adequate or missing RMM: in $81.6 \%$ procedures of work, $65.8 \%$ guardrails and edge protection, $60.5 \%$ risk assessment, and $60.5 \%$ platforms or scaffolds. It can be concluded that falls from height pose a significant risk for workers, which could be prevented by adequately apply RMM.
\end{abstract}

Implications for theory and practice: The focus in the prevention of falls should be given on most common RMM.

Keywords

Injury. Fall accidents. Risk control. Workplace fatalities. Safety in construction.

How to cite this article: Zlatar, T., Lago, E. M. G., Soares, W. A., Baptista, J. S., \& Barkokébas Junior, B. (2019). Falls from height: analysis of 114 cases. Production, 29, e20180091. https://doi.org/10.1590/0103-6513.20180091.

Received: Oct. 11, 2018; Accepted: Apr. 10, 2019.

\section{Introduction}

Every day, people die as a result of occupational accidents or work-related diseases. In total, it reaches more than 2.78 million deaths and some 374 million non-fatal work-related injuries and illnesses each year (International Labour Organization, 2017). The human cost of this daily adversity is vast, and the economic burden of poor occupational safety and health practices is estimated at 3.94\% of global Gross Domestic Product each year (International Labour Organization, 2017). Globally, among all, unintentional injuries represent a major public health problem and a leading cause of deaths (Centers for Disease Control and Prevention, 2017). After road traffic injuries, falls represent the second leading cause of unintentional injury deaths worldwide. An estimation is a number of 646000 fatal falls and some 37.3 million non-fatal falls each year, severe enough to require medical attention (World Health Organization, 2017). The construction industry represents the most influential group in these numbers, with around $21.4 \%$ of USA's workers fatalities, where the leading causes were falls (38.8\%) (Occupational Safety and Health Administration, 2017) and around 31\% of UK's workers fatalities, where the primary cause of falls from height $(20 \%)$ (Bomel, 2003). The severity of fall-risk was investigated in many studies, analyzing the risk depending on occupation, age and location (Beavers et al., 2006; Dong et al., 2009; Johnson et al., 1999). Some went further, analyzing heights from which people mostly fell, the type and value of projects where fall-accidents mostly occurred (Huang et al., 2003; Kang et al., 2017). 
Despite all of these studies and the risk of falling from height is clearly identified as a challenge to be solved. Even after several studies have investigated the reasons why they continue to occur and solutions to minimize hazards or eliminate their risk, the number of accidents due to falls from height continues to grow.

The objective of this study was to analyze the consequences depending on falling height and to investigate the risk management measures that were commonly missing or not adequately applied in preventing and controlling at the time when falls from height occurred.

\section{Methodology}

The methodology of this review was based on the PRISMA Statement for Reporting Systematic Reviews and Meta-Analyses (Liberati et al., 2009). The searching process was conducted by using the Brazilian CAPES searching tool (Coordenação de Aperfeiçoamento de Pessoal de Nivel Superior, 2017), by using the institutional IP address of the University of Pernambuco federate credentials. The following two keywords were defined: "fall" AND "height". The selection process included first applying the exclusion, and afterward inclusion criteria.

\subsection{Exclusion and inclusion criteria}

The review only included court cases, as studies, published in the English language by the journal "Safety \& Health Practitioner" (Institution of Occupational Safety \& Health, 2017), as this journal made all the analyzed information open access. Afterward, the studies were excluded if repeated, then screened and excluded by title, considering only those related to falls from height, excluding if the fall height was unknown, if falls were from a standing height, if the person fell on material which absorbed the impact, or if suffered multiple falls. As inclusion criteria, only accidents were considered, while suicidal and homicidal events were excluded.

Additionally, this study included a previously conducted systematic review on falls from height (Zlatar \& Barkokébas, 2018). This article serves as state of the art on the topic of falls from height, give indicators for the data analysis (fall accidents by height and by location) and develop the discussion part by comparing the results from this study with the results from previously conducted studies.

\subsection{Data analysis}

Statistical analysis was done by using excel statistical toolbox. The data were analyzed in accordance with rules specified in the following sections:

A) Fall height and place

In order to be able to compare data with previous studies (Huang et al., 2003; Kang et al., 2017), the cases were distributed in four height-groups as given by previous studies:

- Falls from a height between 0 to $3 \mathrm{~m}$;

- Falls from a height between 3 to $6.1 \mathrm{~m}$;

- Falls from a height between 6.1 to $9.0 \mathrm{~m}$;

- Falls from a height of more than $9.1 \mathrm{~m}$.

The analyzed results include activities which were conducted before falling, the fall height and where it occurred.

B) Consequence analysis

In order to better analyze the consequences of falls from height, the cases were divided into four groups according to the consequences:

- Nothing injured (bruising, minor burns, and blisters, minor cuts on the head);

- Temporary disability (fractured leg, ankle, ribs);

- Permanent disability (serious spinal injuries or paralyzed from the waist down); 
- Death (including instant death and death which occurred after some time, but which was related to injuries suffered by the fall).

The consequences of the falls were then related and grouped according to the height of fall, determined by studies previously mentioned section in the "A) Determination of fall-height".

C) Risk management analysis

For risk management analysis, five categories were selected in order to evaluate which measures were applied to prevent and control workplace hazards, and therefore minimize or eliminate safety hazards. For this study, the NIOSH recommendations (National Institute for Occupational Safety and Health, 2018) on the hierarchy of controls were reflected, considering the following categories and measures:

- Risk Assessment (including identification and evaluation of the risk);

- Elimination (to physically remove the hazard) or Substitution (to replace the hazard);

- Engineering Controls (to isolate people from the hazard, including the use of work platforms, scaffolds, ladders, stepladders, guardrails, handrails, barriers, edge protection, and nets);

- Administrative Controls (to change the way people work, including procedure, method, and plan of work, training certification, signs, lighting, warning labels, and supervision);

- Personal Protective Equipment - PPE (to protect the worker).

This recommendation is commonly accepted by Safety at work engineers and practitioners to always start with the most effective possible measure (elimination), and when not feasible to apply it, go to the next measure of the hierarchy.

\section{Results}

The identification process resulted in 386 studies. All were screened thoroughly in order to exclude those that were not in accordance with the exclusion and inclusion criteria. Finally, 114 cases were included in this analysis (illustrated in Table $1 \mathrm{~A}$ of the Appendix A).

\subsection{Fall height and place}

In the included studies, falling height ranged between 1.2 to 42 meters, where the numbers were: 19 cases between 0 to $3 \mathrm{~m}$; 52 cases between 3 to $6.1 \mathrm{~m} ; 21$ cases between 6.1 to $9.0 \mathrm{~m}$; and 22 cases of more than $9.1 \mathrm{~m}$. The distribution of cases per group is illustrated in Figure 1.

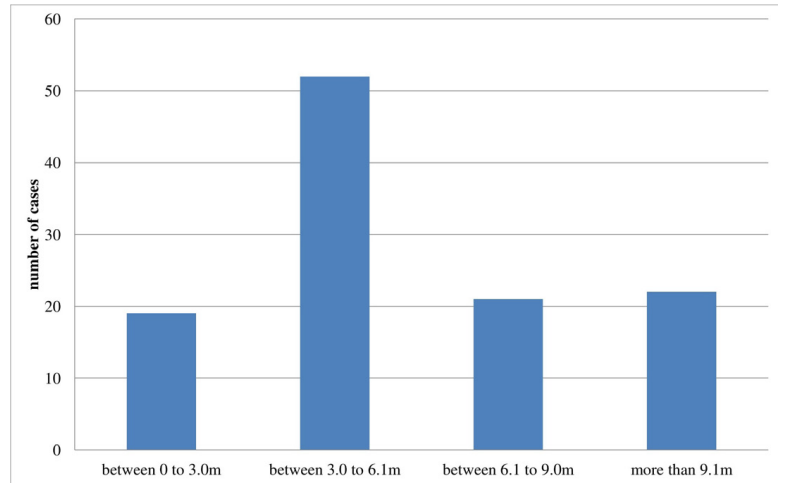

Figure 1. Distribution of encountered cases by fall height.

The location of all included cases was in the United Kingdom, ranging from the year 2003 to 2014. Nevertheless, this review did not analyze fall cases fluctuation during the years on one specific territory, but was primarily focused on consequences depending on fall height, among other analyzed questions. The building height and 
type was not specified by included articles. The type of working activity was mostly (in 65 cases, 57\%) related to construction working activities (building, reforming or demolishing buildings), in three cases it was related to leisure time, while other (in 46 cases) were related to other working activities, such as sewage maintenance, vehicle repairing or boat building.

Figure 2 illustrates the most common places where falls from height occurred: on scaffolds/platforms (26-22.8\%); roofs (30-26.3\%); collapses, including collapses of floors, walls and staircases (4-3.5\%); through opening, including falls through stairwells, trapdoors, lift wells or the glass panels in construction (15-13.2\%); ladders and stepladders (10-8.8\%); lifting, including lifting's with forklifts (10-8.8\%), and other (19-16.7\%).

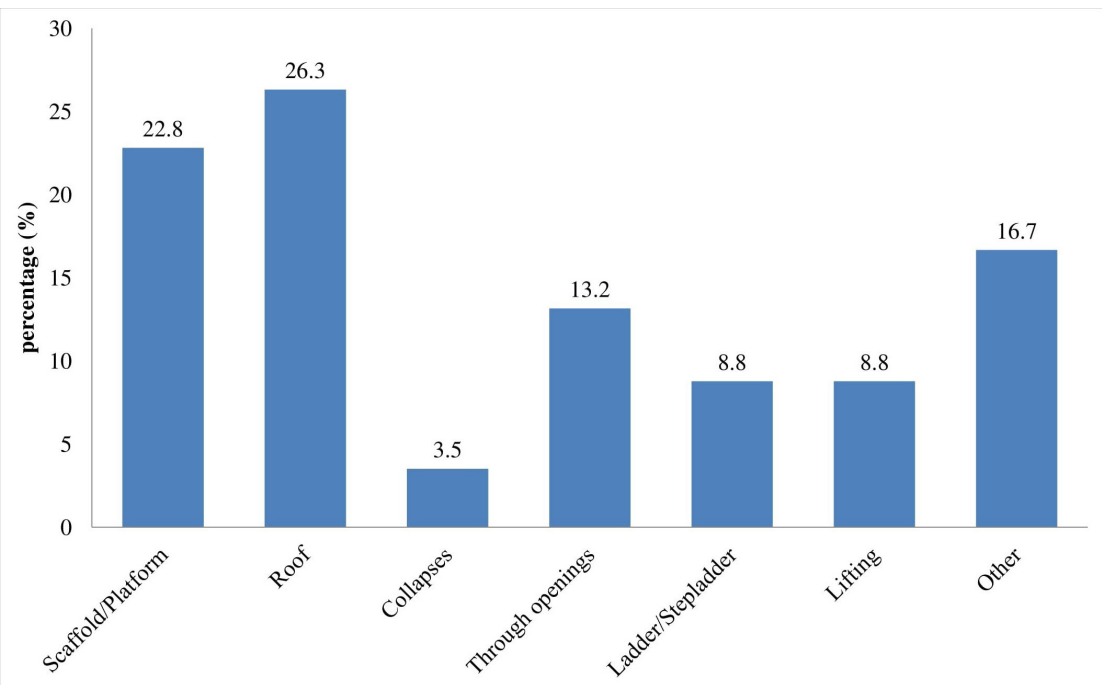

Figure 2. Most common places for falls from heights.

\subsection{Consequence analysis}

The consequences depending on fall height were illustrated in Table 1, showing the number of cases and percentages for each of the four analyzed consequences.

As it could be seen from the Table 1, the consequence of not having anything injured was present only in fall heights below 6.1 meters.

Table 1. Fall consequences per height groups.

\begin{tabular}{cccccc}
\hline Fall height $(\mathrm{m})$ & Nothing injured & Temporary disability & Permanent disability & Death & Total \\
\hline between 0 to 3.0 & $1(5 \%)$ & $12(63 \%)$ & $4(21 \%)$ & $2(11 \%)$ & $19(100 \%)$ \\
between 3.0 to 6.1 & $4(8 \%)$ & $27(52 \%)$ & $8(15 \%)$ & $13(25 \%)$ & $52(100 \%)$ \\
between 6.1 to 9.0 & $0(0 \%)$ & $8(38 \%)$ & $3(14 \%)$ & $10(48 \%)$ & $21(100 \%)$ \\
$\geq 9.1$ & $0(0 \%)$ & $4(18 \%)$ & $2(9 \%)$ & $16(73 \%)$ & $22(100 \%)$ \\
Global & $5(4 \%)$ & $51(45 \%)$ & $17(15 \%)$ & $41(36 \%)$ & $114(100 \%)$ \\
\hline
\end{tabular}

\subsection{Risk management analysis}

Figure 3 illustrates missing or non-adequate safety procedures. In total, 5 main categories with 11 measures were illustrated: category 1 - identification, evaluation and risk control (measure 1); category 2 - risk elimination/ prevention (measure 2); category 3 - engineering controls and measures (measures 3, 4, 5 and 6); category 4 - administrative controls and measures (measures 7, 8, 9 and 10); and category 5 - using of PPE. The data for each analyzed measure was divided into: missing (if the measure was not applied); not adequate (if the measure was not appropriate); additionally (if the measure should be revised if appropriate); and total (the total number the three mentioned situations). 


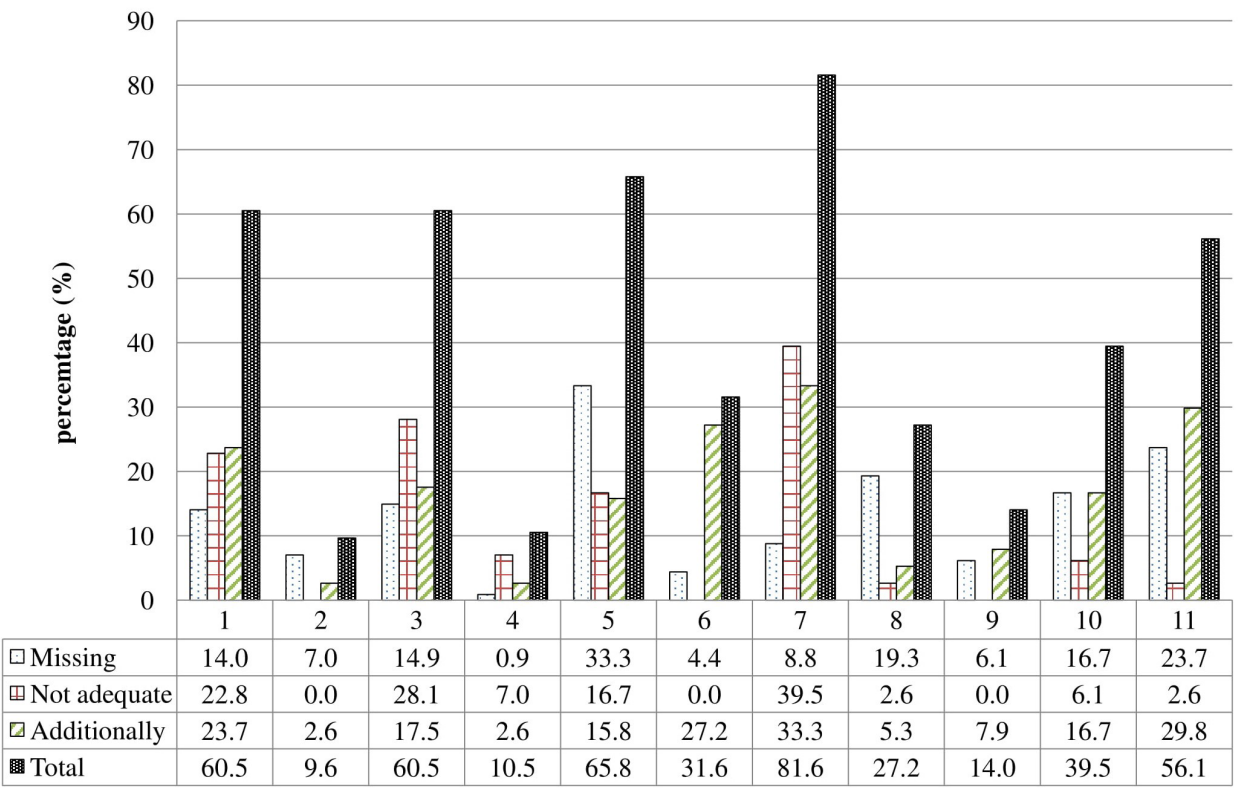

Figure 3. Measures failed while working at heights. Measures: (1) Risk Assessment; (2) Risk Elimination (Prevention); (3) Work platform, Scaffold; (4) Ladder/Stepladder; (5) Guardrails, Handrails, Bariers, Edge Protection; (6) Nets; (7) Procedure of work (method, plan); (8) Training and Certification; (9) Signs, Lighting, Warning labels; (10) Supervision; (11) Personal Protective Equipment.

\section{Discussion}

\subsection{Fall height and place}

Table 2 illustrates groups depending on falling height and compares the results from this study with results from two other studies. It is important to notice that percentages were a product of the analyzed cases and that in reality, it is probable to expect a much higher number of falls from lower heights, where falls are probably passing not recorded.

Table 2. Fall accidents by height.

\begin{tabular}{cccc}
\hline Fall height $(\mathrm{m})$ & This study & Kang et al. (2017) & Huang et al. (2003) \\
\hline between 0 to 3.0 & $16.7 \%$ & $22.1 \%$ & $23.0 \%$ \\
between 3.0 to 6.1 & $45.6 \%$ & $42.5 \%$ & $28.0 \%$ \\
between 6.1 to 9.0 & $18.4 \%$ & $6.8 \%$ & $9.0 \%$ \\
$\geq 9.1$ & $19.3 \%$ & $15.5 \%$ & $40.0 \%$ \\
\hline
\end{tabular}

As it could be concluded from Table 2, this study found a lower number of cases with falling heights between 0 to 3.0 meters. The results from falling heights between 3.0 to 6.1 meters are in accordance with the findings from one study (Kang et al., 2017). The percentage of falls between 6.1 to 9.0 meters was higher, while the percentage of falls from heights $\geq 9.1$ meters was in between both previously conducted studies.

In Table 3, the fall accidents by location were compared with findings from other studies.

Table 3. Fall accidents by location.

\begin{tabular}{cccc}
\hline Location of falls & This study & Kang et al. (2017) & Huang et al. (2003) \\
\hline Scaffold & $22.8 \%$ & $19.5 \%$ & $15.4 \%$ \\
Roof & $26.3 \%$ & $24.7 \%$ & $28.7 \%$ \\
Through opening (other than roof) & $13.2 \%$ & $5.6 \%$ & $7.7 \%$ \\
Ladder & $8.8 \%$ & $16.0 \%$ & $13.0 \%$ \\
Lifting & $8.8 \%$ & $5.3 \%$ & $3.2 \%$ \\
Other & $16.7 \%$ & $28.9 \%$ & $32.0 \%$ \\
\hline
\end{tabular}


Data analyzed through this review show that falls from height occur mostly when working on roofs, scaffolds, and platforms, representing almost 50\% of all analyzed cases. Therefore, workers working at these positions are most endangered, were all mentioned risk management measures and procedures should be applied and revised on a regular basis. In accordance with the Table 3, some studies concluded that scaffolders and roofers are among the most exposed working activities, which is understandable as they spent more time working on heights (Bobick, 2005; Wong et al., 2016), and as they typically carry heavy and bulky materials on slippery and inclined walking/working surfaces (Wiersma \& Charles, 2006). Further-on, innovative safety solutions should be considered, because as compared with one study (Cheung \& Chan, 2012) comparing scaffolds, it could benefit to the safety of workers, reduce the cost of the equipment in use, increase durability and speed of setting the equipment, among other advantages. Most of the challenges about falls from height might be solved through tools (Ezisi \& lssa, 2018) for implementing the approach of Prevention through Design.

\subsection{Consequence of falls from height}

Other studies did not analyze the consequence of falls from height; therefore it was not possible to compare the results. By comparing consequences among analyzed studies, the number of cases which resulted in no injury was very low $(5 ; \approx 4 \%$ of all analyzed cases). With only 5 cases it could be assumed that this is probably the most biased category, as it is reasonable to assume that many low-altitude fall cases happen on a daily basis, but most of them end with no or light injuries, therefore ending up unreported.

The number of cases which resulted in a temporary disability was the highest $(51 ; \approx 45 \%$ of all analyzed cases). Although workers did not suffer the more severe consequence, it can be seen that falls from height temporarily disabled further working activities, where it is probable to expect rehabilitation costs and loss of production.

Serious consequences were represented in a high number of cases, the permanent disability was encountered in $17(\approx 15 \%)$, while deaths in $41(\approx 36 \%$ of all analyzed cases). The fatal falls from a height above $9.1 \mathrm{~m}$ were responsible for $33.9 \%$ of fatal falls, which is in accordance with the findings from another study where falls above $9.1 \mathrm{~m}$ (30 feet in the article) were accounted for more than one-third of fatal falls (Dong et al., 2017).

Figure 4 illustrates the severity of the consequence depending on fall height (distance) and the percentage of occurrence of each consequence. It also illustrates the logarithmic tendency lines (chosen because they minimize the overall $R^{2}$ value) with their equations for each consequence. The severity of injuries varied according to the falling height. Although falling from any altitude may result in any of considered consequences, the results show that falls from heights above $20 \mathrm{~m}$ should result in death consequence, while other consequences could happen only by chance, therefore set up to height until $20 \mathrm{~m}$. Some cases were removed for the construction of the interpolations as have been considered as cases by chance and therefore withdrawn from Figure 4 (For example, the percentage of death consequences gradually increased as falling height increased, reaching $75 \%$ of death cases on height of $10 \mathrm{~m}$, and then being 100\% on heights from 12 to $42 \mathrm{~m}$. From analyzed data, on falling height of $16 \mathrm{~m}$, there was a death consequence of 50\%, not following the logical trend, and therefore considered as cases by chance and withdrawn from the figure).

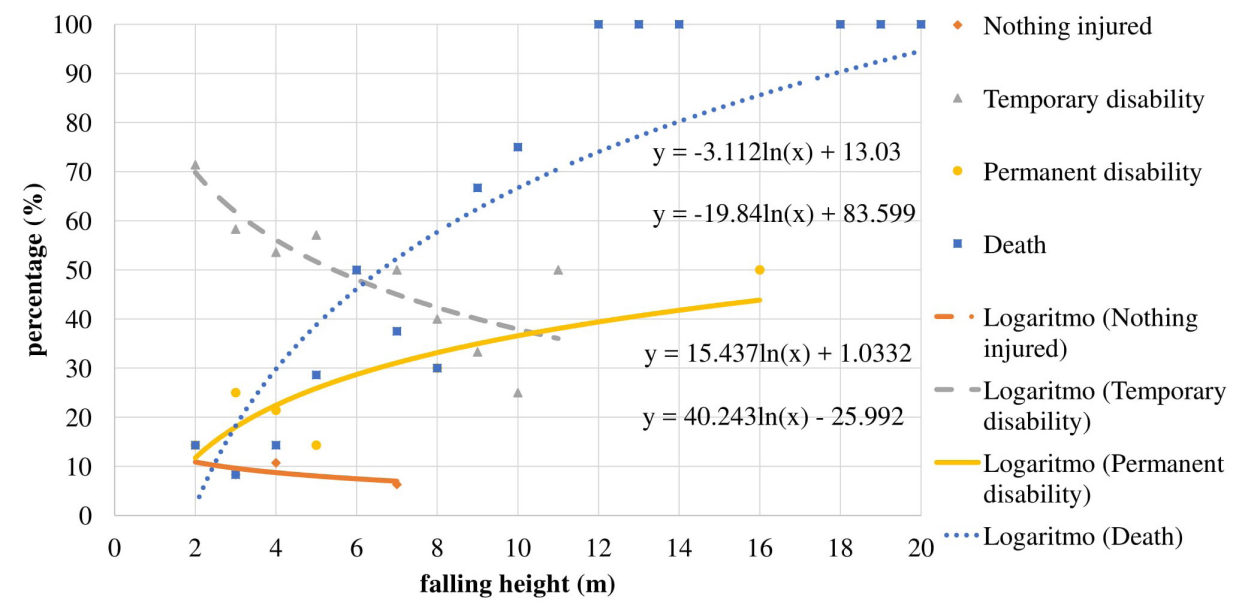

Figure 4. Consequences depending on falling height. 
The Figure 4 illustrating the tendencies of consequences depending of falling height, show that as the fall height increase there was a tendency of:

- Decrease for consequence "nothing injured" $(y=-3.112 \ln (x)+13.03)$;

- Decrease for consequence "temporary disability” $(y=-19.84 \ln (x)+83.599)$;

- Increase for consequence "permanent disability" ( $y=15.437 \ln (x)+1.0332)$;

- Increase for consequence "death" ( $y=40.243 \ln (x)-25.992)$.

It is also important to notice that in some cases a consequence resulted in temporary disability, while it could as easily result with death. For example, in one case fall resulted in a person being on life support machines for 10 days (The Safety \& Health Practitioner, 2006b) or in another case, being unable to return to work for 2 years (The Safety \& Health Practitioner, 2013b).

The lowest altitude from which the person died was $1.8 \mathrm{~m}$. By analyzing death cases from low altitudes, it was noticed that all died due to falling headfirst, received severe head injuries, fractured skulls or hit their head on the kerb (The Safety \& Health Practitioner, 2005, 2006a, 2009, 2010a, b, 2013a). These findings are in accordance with a study (Türk \& Tsokos, 2004) which found that head trauma was the cause of death in 11 of the 19 cases that were from $9 \mathrm{~m}$ or less (58\%). Therefore, as head injuries were found to be responsible for deaths on lower heights, it can be concluded that helmets would be an effective life-protection equipment for lower heights. On the other hand, analyzed deaths from heights over 10m (Türk \& Tsokos, 2004) were caused mainly due to polytrauma ( $72 \%)$, and in only $\approx 24 \%$ cases $(8 / 33)$ by head trauma.

In practice, falls from height typically occur when carrying heavy and bulky materials on slippery and inclined walking/working surfaces (Wiersma \& Charles, 2006). Therefore, for working activities when this is the case, wearing helmets could be considered for activities on the same level, while for activities on height, special attention should be taken in applying risk management measures.

\subsection{Risk management analysis}

Figure 3 illustrates a total percentage of 11 failed risk management measures for analyzed cases. The administrative measure - the procedure of work (method and plan) was found to be the most common safety measure noted as "not adequate" or as "should be revised", within $81.6 \%$ of analyzed cases. The engineering measure - guardrails, handrails, barriers and edge protection were found to be the second most failed safety measure with $65.8 \%$ (where it was missing in 33.3\% of cases). Further two most commonly failed measures were risk assessment $(60.5 \%)$ and the engineering measure - work platform/scaffold (60.5\%). Inadequate PPE or missing PPE was noticed in $56.1 \%$ of the cases. By comparison, one previously conducted study found that in $48 \%$ of the cases workers fell due to their loss in balance while not wearing adequate fall protection devices (Wong et al., 2016).

It is also interesting to notice that training and certification were missing in $19.3 \%$ of the workers. This is important because training increases workers' perception and reaction to risk and, when conducted regularly, can improve safety performance and therefore the worker is more likely to identify, evaluate and control risks (Chan et al., 2008; Hinze \& Gambatese, 2003; Rodríguez-Garz et al., 2015). In addition, it is essential to consider that training should be conducted in accordance with the individual characteristics of workers as age, position, trade, number of years of work, past experience with accidents, and personality, which was all found to contribute on how effective would be the training (Kim et al., 2011). Kang found that workers were not equipped with fall protection in 70.7\% of cases, and were equipped incorrectly in 17.9\% of cases (Kang et al., 2017). Although this could not be directly compared with results from this study, the same conclusions could be adopted - there is an urgent need to improve working safety culture and adopt adequate occupational risk management measures.

Missing or not adequate supervision was found in $22.8 \%$ of the analyzed cases. One study found that supervision is important as scaffolders failed to anchor their harness, not due to poor safety attitude, but due to a subjective norm (perceived social pressure) (Goh \& Binte Sa'adon, 2015).

The 11 risk management measures illustrated in Figure 3 were further analyzed by each case separately. It was noted that most of the cases had failed several risk management measures. In the following Figure 5 were illustrated all 114 cases $(100 \%)$ by the number of failed risk management measures (both missing and not adequate risk management measures) by each case, where 1 failed measure was only present in $2 \%$ of analyzed cases, 2 failed measures in 15\%, 3 in 19\%, 4 in 20\%, 5 in 15\%, 6 in 19\% and 7 in 10\% of analyzed cases.

As it is shown in Figure 5, only 2\% of the analyzed cases could be associated with one failed risk management measure, while in other $98 \%$, the fall from height was a result of several non-adequate or missing risk 


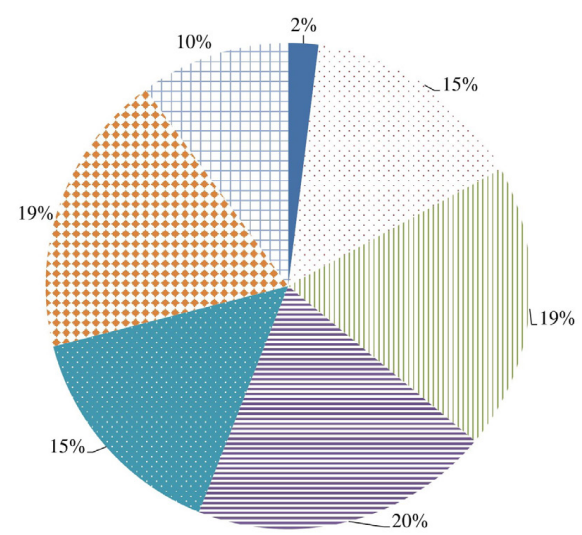

Figure 5. Number of failed risk management measure from the analyzed cases.

management measures. Therefore, it is possible to conclude that in the majority of cases, falls from height were not a coincidence or an unlucky event due to only one fail, but that it could be promptly easily noted due to various failures, and prevented with daily safety screening of the working process.

\subsection{Future studies}

In order to be able to analyze fall consequences further and understand better how some factors benefit to the survival of falling from greater heights, there is a need to include more data on persons which fell and explain how it occurred. For example, fall (impact) energy could be calculated through data on fall height and human body mass: $E=m g h(\mathrm{~J})$.

Results on calculations regarding fall energy for four different persons (body mass of 60, 75, 90 and 105kg) were illustrated in Figure 6.

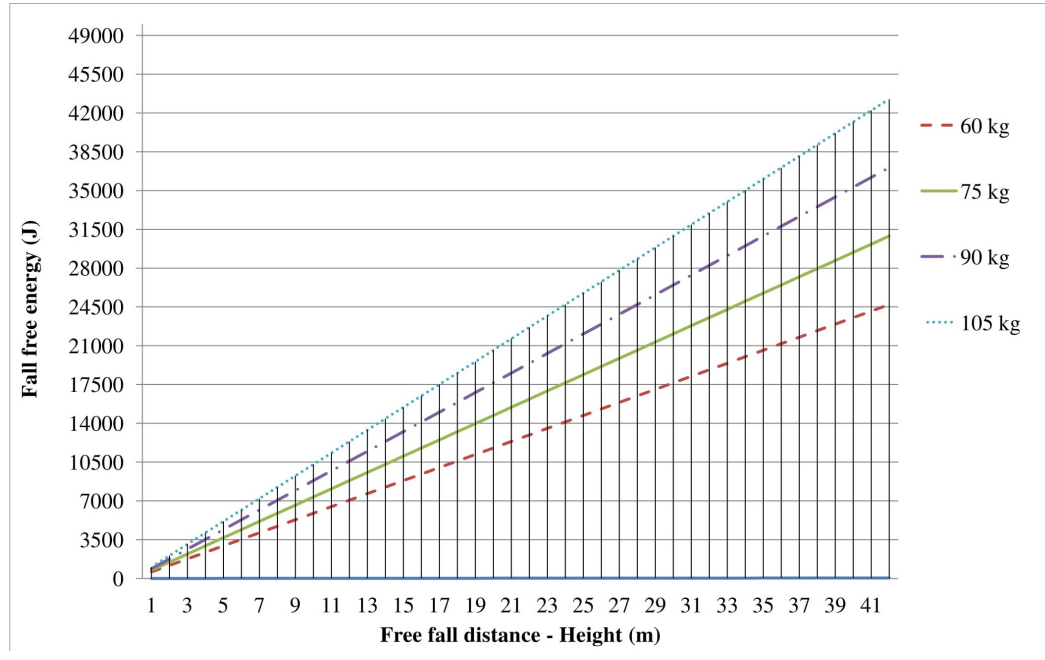

Figure 6. Human body mass an its relation to fall energy and fall height.

As it is illustrated in Figure 6, the fall energy of 10,500 correspond to fall of a human with a body mass of $105 \mathrm{~kg}$ from a height of $10 \mathrm{~m}, 90 \mathrm{~kg}$ from $12 \mathrm{~m}, 75 \mathrm{~kg}$ from $14 \mathrm{~m}$ and $60 \mathrm{~kg}$ from $18 \mathrm{~m}$. Therefore, a fall impact from the same height would be much lower for those humans having lower body mass compared with those with higher, representing a heavy person less chance of surviving a fall.

Future studies should also consider exploring with more details the employment conditions of workers which suffered falls from height, including the type of employment contract, the age, and experience of the worker. 


\section{Limitations}

The limitations of this study lay in analyzing cases which were reported and recorded by the reviewed source. A bias probably lays in the number of no reported cases of falls from height, especially when the fall resulted in minor or no injuries which could be expected in falls from lower heights. Therefore, the percentages on injuries and death occurrences might not correspond to actual values, especially for lower heights. Finally, the analyzed data do not contain information on workers body mass, which would be interesting to analyze as it might have influenced the energy of fall impact, explaining why some persons survived falls from greater heights. Analyzing more cases would help in more consistent results and therefore understanding better the consequences of falls from heights, and possibly result with more or different consequence-based groups.

\section{Conclusions}

The falls from height represent one of the leading risks, causing more than 2.78 million deaths and some 374 million non-fatal work injuries each year. Through the analysis of included studies, it was found that a typical accident of falls from height would be in 45.6\% from heights between 3 to 6.1 meters and in $49.1 \%$ occurring from scaffolds or roofs. The consequences this fall would result in death if the person fell on head and suffered head trauma, while if not, the percentage representing survival would be $\approx 55 \%$, depending on the persons mass and also material on which he would fall. As the data show, there would be a percentage of $\approx 98 \%$ that several risk assessment measures were not applied. Among those not applied (failed) measures the reason would be: in $81.6 \%$ the procedures of work (administrative measure); in 65.8\% the guardrails, handrails, barriers and edge protection (engineering measure); in 60.5\% risk assessment; and in 60.5\% work platform/scaffold (engineering measure). Therefore, it can be concluded that falls from height pose a great risk for workers, which could be prevented by adequately apply management measures.

Future studies should include more cases with data on body mass of persons which fell from heights, and evaluate how falling height affect each body part.

\section{Acknowledgements}

This project was financially supported by the Brazilian Ministry of Education through the Program for Coordination and Improvement of Higher Level Personnel (PNPD/CAPES). Many thanks for all the support from the Faculty of Engineering, University of Porto (FEUP), Federal University of Pernambuco (UFPE) and to the University of Pernambuco (UPE).

\section{References}

Beavers, J. E., Moore, J. R., Rinehart, R., \& Schriver, W. R. (2006). Crane-related fatalities in the construction industry. Journal of Construction Engineering and Management, 132, 901-910. http://dx.doi.org/10.1061/(ASCE)0733-9364(2006)132:9(901).

Bobick, T. G. (2005). Falls through roof and floor openings and surfaces, including skylights: 1992-2000. Journal of Construction Engineering and Management, 130(6), 895-907. http://dx.doi.org/10.1061/(ASCE)0733-9364(2004)130:6(895).

Bomel. (2003). Falls from height: prevention and risk control effectiveness (Research Report, 428). Sudbury: HSE Books.

Centers for Disease Control and Prevention - CDC. (2017). Ten leading causes of death and injury. Retrieved in 2017, November 30, from https://www.cdc.gov/injury/wisqars/LeadingCauses.html

Chan, A. P. C., Wong, F. K. W., Chan, D. W. M., Yam, M. C. H., Kwok, A. W. K., Lam, E. W. M., \& Cheung, E. (2008). Work at height fatalities in the repair, maintenance, alteration, and addition works. Journal of Construction Engineering and Management, 134, 527-535. http://dx.doi.org/10.1061/(ASCE)0733-9364(2008)134:7(527).

Cheung, E., \& Chan, A. P. C. (2012). Rapid demountable platform (RDP): a device for preventing fall from height accidents. Accident Analysis \& Prevention, 48, 235-245. http://dx.doi.org/10.1016/j.aap.2011.05.037. PMid:22664686.

Coordenação de Aperfeiçoamento de Pessoal de Nível Superior - CAPES. (2017). Portal Periódicos CAPES. Retrieved in 2017, August 11, from http://www.periodicos.capes.gov.br/

Dong, X. S., Fujimoto, A., Ringen, K., \& Men, Y. (2009). Fatal falls among Hispanic construction workers. Accident Analysis \& Prevention, 41(5), 1047-1052. http://dx.doi.org/10.1016/j.aap.2009.06.012. PMid:19664444.

Dong, X. S., Largay, J. A., Choi, S. D., Wang, X., Cain, C. T., \& Romano, N. (2017). Fatal falls and PFAS use in the construction industry: findings from the NIOSH FACE reports. Accident Analysis \& Prevention, 102, 136-143. http://dx.doi.org/10.1016/j.aap.2017.02.028. PMid:28292698.

Ezisi, U., \& lssa, M. H. (2018). Case study application of prevention through design to enhance workplace safety and health in Manitoba heavy construction projects. Canadian Journal of Civil Engineering, (204), 1-36.

Goh, Y. M., \& Binte Sa'adon, N. F. (2015). Cognitive factors influencing safety behavior at height: a multimethod exploratory study. Journal of Construction Engineering and Management, 141(6), 1-8. http://dx.doi.org/10.1061/(ASCE)C0.1943-7862.0000972. 
Hinze, J., \& Gambatese, J. (2003). Factors that influence safety performance of specialty contractors. Journal of Construction Engineering and Management, 129, 159-164. http://dx.doi.org/10.1061/(ASCE)0733-9364(2003)129:2(159).

Huang, X., Hinze, J., \& Asce, M. (2003). Analysis of construction worker fall accidents. Journal of Construction Engineering and Management, 129, 262-271. http://dx.doi.org/10.1061/(ASCE)0733-9364(2003)129:3(262).

Institution of Occupational Safety \& Health. (2017). The safety \& health practitioner. Retrieved in 2017, October 20, from http://www. shponline.co.uk/

International Labour Organization - ILO. (2017). Safety and health at work. Retrieved in 2017, November 30, from http://www.ilo.org/ global/topics/safety-and-health-at-work/lang--en/index.htm

Johnson, H. M., Singh, A., \& Young, R. H. F. (1999). Fall protection analysis for workers on residential roofs. Journal of Construction Engineering and Management, 124(5), 418-428. http://dx.doi.org/10.1061/(ASCE)0733-9364(1998)124:5(418).

Kang, Y., Siddiqui, S., Suk, S. J., Chi, S., \& Kim, C. (2017). Trends of fall accidents in the U. S. construction industry. Journal of Construction Engineering and Management, 143(8), 1-7. http://dx.doi.org/10.1061/(ASCE)C0.1943-7862.0001332.

Kim, E., Yu, 1., Kim, K., \& Kim, K. (2011). Optimal set of safety education considering individual characteristics of construction workers. Canadian Journal of Civil Engineering, 38(5), 506-518. http://dx.doi.org/10.1139/111-024.

Liberati, A., Altman, D. G., Tetzlaff, J., Mulrow, C., Gøtzsche, P. C., loannidis, J. P., Clarke, M., Devereaux, P. J., Kleijnen, J., \& Moher, D. (2009). The PRISMA statement for reporting systematic reviews and meta-analyses of studies that evaluate health care interventions: explanation and elaboration. Annals Internal Medicine, 151(4), W65-94. http://dx.doi.org/10.7326/0003-4819-151-4-20090818000136. PMid:19622512.

National Institute for Occupational Safety and Health - NIOSH. (2018). Hierarchy of controls. Washington.

Occupational Safety and Health Administration - OSHA. (2017). Construction's "fatal four". Retrieved in 2017, November 9, from https://www.osha.gov/oshstats/commonstats.html

Rodríguez-Garz, 1., Lucas-Ruiz, V., Martínez-Fiestas, M., \& Delgado-Padial, A. (2015). Association between perceived risk and training in the construction industry. Journal of Construction Engineering and Management, 141(5), 1-9. http://dx.doi.org/10.1061/(ASCE) C0.1943-7862.0000960.

The Safety \& Health Practitioner. (2005). Fall from height: unsecured ladder implicated in worker's fatal fall. Retrieved in 2017, October 15, from http://link.galegroup.com/apps/doc/A132848205/AONE?u=capes\&sid=AONE\&xid=21 be3201

The Safety \& Health Practitioner. (2006a). Fall from height: engineer fell from forklift truck while repairing door. Retrieved in 2017, October 15, from http://link.galegroup.com/apps/doc/A143775620/AONE?u=capes\&sid=AONE\&xid=711 faf9d

The Safety \& Health Practitioner. (2006b). Fall from height: three firms fined over bus garage plunge. Retrieved in 2017, 0ctober 15, from http://link.galegroup.com/apps/doc/A141175247/AONE?u=capes\&sid=AONE\&xid=a3f90bf6

The Safety \& Health Practitioner. (2009). Company director “wholly culpable”. Retrieved in 2017, October 15, from http://link.galegroup. com/apps/doc/A204090998/A0NE?u=capes\&sid=AONE\&xid=e226e $1 \mathrm{db}$

The Safety \& Health Practitioner. (2010a). Construction firm fined over death at premier-league club. Retrieved in 2017, 0ctober 15, from http://link.galegroup.com/apps/doc/A243044576/AONE?u=capes\&sid=AONE\&xid=cb36c9a5

The Safety \& Health Practitioner. (2010b). Death of Polish worker a wake-up call to construction bosses. Retrieved in 2017, October 15, from http://link.galegroup.com/apps/doc/A218591885/AONE?u=capes\&sid=AONE\&xid=e744f410

The Safety \& Health Practitioner. (2013a). Lack of work-at-height checks contributed to ladder death. Retrieved in 2017, October 15, from http://link.galegroup.com/apps/doc/A318915529/AONE?u=capes\&sid=AONE\&xid=1607eff8

The Safety \& Health Practitioner. (2013b). Miscommunication led to worker's stairwell plunge. Retrieved in 2017, October 15, from http://link.galegroup.com/apps/doc/A341129969/AONE?u=capes\&sid=AONE\&xid=e790bfb 1

Türk, E. E., \& Tsokos, M. (2004). Pathologic features of fatal falls from height. The American Journal of Forensic Medicine and Pathology, 25(3), 194-199. http://dx.doi.org/10.1097/01.paf.0000136441.53868.a4. PMid:15322459.

Wiersma, M., \& Charles, M. (2006). Occupational injuries and fatalities in the roofing contracting industry. Journal of Construction Engineering and Management, 131(11), 1233-1240.

Wong, L., Wang, Y., Law, T., \& Lo, C. T. (2016). Association of root causes in fatal fall-from-height construction accidents in Hong Kong. Journal of Construction Engineering and Management, 142(7), 1-12. http://dx.doi.org/10.1061/(ASCE)C0.1943-7862.0001098.

World Health Organization - WHO. (2017). Falls. Retrieved in 2017, November 30, from http://www.who.int/mediacentre/factsheets/ fs344/en/

Zlatar, T., \& Barkokébas, B. J. (2018). Building information modelling as a safety management tool for preventing falls from height (1st ed., pp. 15-21). Mauritius: LAP Lambert Academic Publishing. 


\section{Appendix A. Falls from height: analysis of 114 cases.}

This appendix file contains 4 tables, which illustrate all included and analysed cases within the article "Falls from Height: Analysis of 114 Cases":

- Table 1A: Included articles, illustration of the article title, reference, year, type of industry and age of the injured worker;

- Table 2A: Included articles, illustration of the falling height by articles, consequence, injured body parts and recovery period;

- Table 3A: Included articles, illustration of the measures which were Not Appropriate (NA), were missing (0) or should be Additionally (A) considered among each one of included cases;

- Table 4A: Included articles, illustration of accidents which were related to most common falling places.

Table 1A. Included articles, illustration of the article title, reference, year, type of industry and age of the injured worker.

\begin{tabular}{|c|c|c|c|c|c|}
\hline $\mathrm{Nr}$ & Title & Reference & $\begin{array}{l}\text { Fall } \\
\text { year }\end{array}$ & $\begin{array}{l}\text { type of } \\
\text { industry }\end{array}$ & $\begin{array}{l}\text { age of injured } \\
\text { worker (yrs) }\end{array}$ \\
\hline 1 & Fall from height: lack of access equipment led to injury & $\begin{array}{l}\text { The Safety \& Health } \\
\text { Practitioner, May, 2006, } \\
\text { Vol.24(5), p.14(1) }\end{array}$ & 2006 & logistic group & \\
\hline 2 & $\begin{array}{l}\text { Boat-building company sinks below safety standards. (FALL FORM } \\
\text { HE1GHT) }\end{array}$ & $\begin{array}{l}\text { The Safety \& Health } \\
\text { Practitioner, July, 2012, } \\
\text { Vol.30(7), p.15(1) }\end{array}$ & 2012 & boat building & \\
\hline 3 & Fall from height: site visitor fell into unguarded and unlit pit & $\begin{array}{l}\text { The Safety \& Health } \\
\text { Practitioner, Nov, 2006, } \\
\text { Vol.24(11), p.12(1) }\end{array}$ & 2006 & $\begin{array}{l}\text { motor vehicle } \\
\text { repair and } \\
\text { maintenance }\end{array}$ & \\
\hline 4 & Fall from height: ladder fall costs firm & $\begin{array}{l}\text { The Safety \& Health } \\
\text { Practitioner, March, 2006, } \\
\text { Vol.24(3), p.16(1) }\end{array}$ & 2006 & $\begin{array}{l}\text { meat packing } \\
\text { and processing }\end{array}$ & \\
\hline 5 & $\begin{array}{l}\text { Injured worker flouted company policy by borrowing ladder, says } \\
\text { employer. (FALL FROM HEIGHT) }\end{array}$ & $\begin{array}{l}\text { The Safety \& Health } \\
\text { Practitioner, May, 2008, } \\
\text { Vol.26(5), p.16(1) }\end{array}$ & 2008 & dust control & \\
\hline 6 & $\begin{array}{l}\text { Lack of work-at-height checks contributed to ladder death. } \\
\text { (FALL FROM HEIGHT) }\end{array}$ & $\begin{array}{l}\text { The Safety \& Health } \\
\text { Practitioner, Jan, 2013, } \\
\text { Vol.31(1), p.14(1) }\end{array}$ & 2013 & pub cleaning & 65 \\
\hline 7 & Caretaker fell from unprotected platform. (FALL FROM HEIGHT) & $\begin{array}{l}\text { The Safety \& Health } \\
\text { Practitioner, August, } \\
2011, \text { Vol.29(8), p.14(1) }\end{array}$ & 2011 & construction & 54 \\
\hline 8 & $\begin{array}{l}\text { Lightning strikes twice for ladder-fall spray-painter. } \\
\text { (FALL FROM HEIGHT) }\end{array}$ & $\begin{array}{l}\text { The Safety \& Health } \\
\text { Practitioner, Nov, 2012, } \\
\text { Vol.30(11), p.12(1) }\end{array}$ & 2012 & $\begin{array}{l}\text { a truck body } \\
\text { shop }\end{array}$ & 51 \\
\hline 9 & $\begin{array}{l}\text { Double fall during poorly-planned maintenance job. } \\
\text { (FALL FROM HEIGHT) }\end{array}$ & $\begin{array}{l}\text { The Safety \& Health } \\
\text { Practitioner, August, } \\
2012 \text {, Vol.30(8), p.15(1) }\end{array}$ & 2012 & \multirow{2}{*}{$\begin{array}{l}\text { vehicle } \\
\text { engineering } \\
\text { firm }\end{array}$} & \\
\hline 10 & $\begin{array}{l}\text { Double fall during poorly-planned maintenance job. } \\
\text { (FALL FROM HEIGHT) }\end{array}$ & $\begin{array}{l}\text { The Safety \& Health } \\
\text { Practitioner, August, } \\
\text { 2012, Vol.30(8), p.15(1) }\end{array}$ & 2012 & & \\
\hline 11 & Film volunteer badly injured in fall. (FALL FROM HEIGHT) & $\begin{array}{l}\text { The Safety \& Health } \\
\text { Practitioner, July, 2011, } \\
\text { Vol.29(7), p.11(1) }\end{array}$ & 2011 & film firm & 34 \\
\hline 12 & $\begin{array}{l}\text { Fall from height: stage collapse and audience injuries see theatre } \\
\text { companies in the dock }\end{array}$ & $\begin{array}{l}\text { The Safety \& Health } \\
\text { Practitioner, May, 2006, } \\
\text { Vol.24(5), p.16(1) }\end{array}$ & 2006 & \multirow{2}{*}{ theater } & \\
\hline 13 & $\begin{array}{l}\text { Fall from height: stage collapse and audience injuries see theatre } \\
\text { companies in the dock }\end{array}$ & $\begin{array}{l}\text { The Safety \& Health } \\
\text { Practitioner, May, 2006, } \\
\text { Vol.24(5), p.16(1) }\end{array}$ & 2006 & & \\
\hline 14 & $\begin{array}{l}\text { Fall from height: "simple solution" could have prevented fall from } \\
\text { ladder }\end{array}$ & $\begin{array}{l}\text { The Safety \& Health } \\
\text { Practitioner, Oct, 2006, } \\
\text { Vol.24(10), p.18(1) }\end{array}$ & 2006 & unspecified & \\
\hline 15 & $\begin{array}{l}\text { Fall from height: unprotected edge costs electric co [pounds } \\
\text { sterling] } 17 \mathrm{k}\end{array}$ & $\begin{array}{l}\text { The Safety \& Health } \\
\text { Practitioner, May, 2005, } \\
\text { Vol.23(5), p.24(1) }\end{array}$ & 2005 & construction & \\
\hline 16 & Fall from height: unsecured ladder implicated in worker's fatal fall & $\begin{array}{l}\text { The Safety \& Health } \\
\text { Practitioner, May, 2005, } \\
\text { Vol.23(5), p.22(1) }\end{array}$ & 2005 & panel installer & \\
\hline 17 & $\begin{array}{l}\text { Fall from height: accident was "easily avoidable". (Construction } \\
\text { company fined over and accident in which bricklayer falls from the } \\
\text { building) }\end{array}$ & $\begin{array}{l}\text { The Safety \& Health } \\
\text { Practitioner, June, 2006, } \\
\text { Vol.24(6), p.15(1) }\end{array}$ & 2006 & construction & \\
\hline
\end{tabular}


Table 1A. Continued...

\begin{tabular}{|c|c|c|c|c|c|}
\hline $\mathrm{Nr}$ & Title & Reference & $\begin{array}{l}\text { Fall } \\
\text { year }\end{array}$ & $\begin{array}{l}\text { type of } \\
\text { industry }\end{array}$ & $\begin{array}{l}\text { age of injured } \\
\text { worker (yrs) }\end{array}$ \\
\hline 18 & $\begin{array}{l}\text { Fall from height: skull fracture sustained in fall through unguarded } \\
\text { stairwell }\end{array}$ & $\begin{array}{l}\text { The Safety \& Health } \\
\text { Practitioner, Nov, 2005, } \\
\text { Vol.23(11), p.15(1) }\end{array}$ & 2005 & construction & 19 \\
\hline 19 & Internal fall risk overlooked. (FALL FROM HEIGHT) & $\begin{array}{l}\text { The Safety \& Health } \\
\text { Practitioner, March, 2009, } \\
\text { Vol.27(3), p.12(1) }\end{array}$ & 2009 & construction & \\
\hline 20 & Boss cut corners to save money. (FALL FROM HEIGHT) & $\begin{array}{l}\text { The Safety \& Health } \\
\text { Practitioner, Dec, 2009, } \\
\text { Vol.27(12), p.16(1) }\end{array}$ & 2009 & construction & \\
\hline 21 & Builder fractures neck in fall. (FALL FROM HEIGHT) & $\begin{array}{l}\text { The Safety \& Health } \\
\text { Practitioner, Oct, 2013, } \\
\text { Vol.31(10), p.16(1) }\end{array}$ & 2013 & construction & \\
\hline 22 & Company director “wholly culpable”. (FALL FROM HEIGHT) & $\begin{array}{l}\text { The Safety \& Health } \\
\text { Practitioner, July, 2009, } \\
\text { Vol.27(7), p.14(1) }\end{array}$ & 2009 & construction & 53 \\
\hline 23 & $\begin{array}{l}\text { Fall from height: "rubbish" scaffolding costs Norfolk construction } \\
\text { firm }\end{array}$ & $\begin{array}{l}\text { The Safety \& Health } \\
\text { Practitioner, June, 2007, } \\
\text { Vol.25(6), p.14(1) }\end{array}$ & 2007 & construction & \\
\hline 24 & $\begin{array}{l}\text { Construction firm fined over death at premier-league club. } \\
\text { (FALL FROM HEIGHT) }\end{array}$ & $\begin{array}{l}\text { The Safety \& Health } \\
\text { Practitioner, Nov, 2010, } \\
\text { Vol.28(11), p.14(1) }\end{array}$ & 2010 & construction & 42 \\
\hline 25 & Construction giant admits safety oversight. (FALL FROM HEIGHT) & $\begin{array}{l}\text { The Safety \& Health } \\
\text { Practitioner, Feb, 2009, } \\
\text { Vol.27(2), p.14(1) }\end{array}$ & 2009 & construction & \\
\hline 26 & $\begin{array}{l}\text { Death of Polish worker a wake-up call to construction bosses. } \\
\text { (FALL FROM HEIGHT) }\end{array}$ & $\begin{array}{l}\text { The Safety \& Health } \\
\text { Practitioner, Jan, 2010, } \\
\text { Vol.28(1), p.18(1) }\end{array}$ & 2010 & construction & 49 \\
\hline 27 & $\begin{array}{l}\text { Factory worker fell following catalogue of safety errors. } \\
\text { (FALL FROM HEIGHT) }\end{array}$ & $\begin{array}{l}\text { The Safety \& Health } \\
\text { Practitioner, March, 2012, } \\
\text { Vol.30(3), p.14(1) }\end{array}$ & 2012 & boat building & 59 \\
\hline 28 & $\begin{array}{l}\text { Fall from height: corroded ladder snapped in two, hurling worker } \\
\text { to the ground }\end{array}$ & $\begin{array}{l}\text { The Safety \& Health } \\
\text { Practitioner, Nov, 2007, } \\
\text { Vol.25(11), p.18(1) }\end{array}$ & 2007 & $\begin{array}{l}\text { brick and stone } \\
\text { cleaning firm }\end{array}$ & \\
\hline 29 & $\begin{array}{l}\text { Fall from height: engineer fell from forklift truck while repairing } \\
\text { door }\end{array}$ & $\begin{array}{l}\text { The Safety \& Health } \\
\text { Practitioner, March, 2006, } \\
\text { Vol.24(3), p.14(1) }\end{array}$ & 2006 & maintenance & \\
\hline 30 & $\begin{array}{l}\text { Fall from height fatality results in [pounds sterling]75k fine for } \\
\text { major scaffolding firm }\end{array}$ & $\begin{array}{l}\text { The Safety \& Health } \\
\text { Practitioner, June, 2003, } \\
\text { Vol.21(6), p.6(1) }\end{array}$ & 2003 & construction & \\
\hline 31 & Fall from height: missing safety rail contributed to fall & $\begin{array}{l}\text { The Safety \& Health } \\
\text { Practitioner, March, 2005, } \\
\text { Vol.23(3), p.18(1) }\end{array}$ & 2005 & maintenance & \\
\hline 32 & Fall from height: repair job wasn't properly planned & $\begin{array}{l}\text { The Safety \& Health } \\
\text { Practitioner, Dec, } 2006 \text {, } \\
\text { Vol.24(12), p.14(1) }\end{array}$ & 2006 & maintenance & \\
\hline 33 & Fall from height: steelworks fined for uncovered pit hole & $\begin{array}{l}\text { The Safety \& Health } \\
\text { Practitioner, April, 2005, } \\
\text { Vol.23(4), p.24(1) }\end{array}$ & 2005 & construction & \\
\hline 34 & $\begin{array}{l}\text { Fall from height: warning on overloading floors under construction } \\
\text { following collapse }\end{array}$ & $\begin{array}{l}\text { The Safety \& Health } \\
\text { Practitioner, March, 2008, } \\
\text { Vol.26(3), p.16(1) }\end{array}$ & 2008 & construction & \\
\hline 35 & $\begin{array}{l}\text { Forklift service firm didn’t consider risk of working on truck roof. } \\
\text { (FALL FROM HEIGHT) }\end{array}$ & $\begin{array}{l}\text { The Safety \& Health } \\
\text { Practitioner, Nov, 2011, } \\
\text { Vol.29(11), p.16(1) }\end{array}$ & 2011 & $\begin{array}{l}\text { a truck body } \\
\text { shop }\end{array}$ & 29 \\
\hline 36 & $\begin{array}{l}\text { Legoland hits back at HSE over "unjustified" prosecution. } \\
\text { (FALL FROM HEIGHT) }\end{array}$ & $\begin{array}{l}\text { The Safety \& Health } \\
\text { Practitioner, March, 2013, } \\
\text { Vol.31(3), p.16(1) }\end{array}$ & 2013 & maintenance & 42 \\
\hline 37 & $\begin{array}{l}\text { Pound stretcher fined after teenage employee breaks ankle. } \\
\text { (FALL FROM HEIGHT) }\end{array}$ & $\begin{array}{l}\text { The Safety \& Health } \\
\text { Practitioner, August, } \\
2006, \text { Vol.24(8), p.14(1) }\end{array}$ & 2006 & unspecified & 16 \\
\hline 38 & $\begin{array}{l}\text { Recycling firm's risk assessment was unrealistic. } \\
\text { (FALL FROM HEIGHT) }\end{array}$ & $\begin{array}{l}\text { The Safety \& Health } \\
\text { Practitioner, Nov, 2008, } \\
\text { Vol.26(11), p.18(1) }\end{array}$ & 2008 & unspecified & \\
\hline 39 & $\begin{array}{l}\text { Fall from height: worker fined for lifting colleague on forks of } \\
\text { truck }\end{array}$ & $\begin{array}{l}\text { The Safety \& Health } \\
\text { Practitioner, Oct, } 2005 \text {, } \\
\text { Vol.23(10), p.14(1) }\end{array}$ & 2005 & unspecified & \\
\hline
\end{tabular}


Table 1A. Continued...

\begin{tabular}{|c|c|c|c|c|c|}
\hline $\mathbf{N r}$ & Title & Reference & $\begin{array}{l}\text { Fall } \\
\text { year }\end{array}$ & $\begin{array}{l}\text { type of } \\
\text { industry }\end{array}$ & $\begin{array}{l}\text { age of injured } \\
\text { worker (yrs) }\end{array}$ \\
\hline 40 & $\begin{array}{l}\text { Fall from height: McDonald's isn't "lovin' it" after [pounds } \\
\text { sterling]35,000 fine }\end{array}$ & $\begin{array}{l}\text { The Safety \& Health } \\
\text { Practitioner, Jan, 2005, } \\
\text { Vol.23(1), p.14(1) }\end{array}$ & 2005 & maintenance & \\
\hline 41 & $\begin{array}{l}\text { Fall from height: worker fell through unprotected gap in high-rise } \\
\text { platform }\end{array}$ & $\begin{array}{l}\text { The Safety \& Health } \\
\text { Practitioner, Oct, 2006, } \\
\text { Vol.24(10), p.14(1) }\end{array}$ & 2006 & construction & \\
\hline 42 & Fall from height: young worker fell from makeshift platform & $\begin{array}{l}\text { The Safety \& Health } \\
\text { Practitioner, Dec, 2005, } \\
\text { Vol.23(12), p.13(1) }\end{array}$ & 2005 & warehouse & 22 \\
\hline 43 & Fall from height: broken back leads to fines for two firms & $\begin{array}{l}\text { The Safety \& Health } \\
\text { Practitioner, May, 2005, } \\
\text { Vol.23(5), p.24(1) }\end{array}$ & 2005 & clothing shop & \\
\hline 44 & Fall from height: worker paralysed in fall through trapdoor & $\begin{array}{l}\text { The Safety \& Health } \\
\text { Practitioner, May, 2006, } \\
\text { Vol.24(5), p.18(1) }\end{array}$ & 2006 & $\begin{array}{l}\text { chemical } \\
\text { manufacturer }\end{array}$ & \\
\hline 45 & $\begin{array}{l}\text { Fall from height: developer fined [pounds sterling] 10,000 after } \\
\text { worker falls through unguarded opening }\end{array}$ & $\begin{array}{l}\text { The Safety \& Health } \\
\text { Practitioner, Dec, 2004, } \\
\text { Vol.22(12), p.18(1) }\end{array}$ & 2004 & construction & 60 \\
\hline 46 & $\begin{array}{l}\text { Fall from height: no surprises as retailer is fined over unguarded } \\
\text { edge }\end{array}$ & $\begin{array}{l}\text { The Safety \& Health } \\
\text { Practitioner, April, 2005, } \\
\text { Vol.23(4), p.19(1) }\end{array}$ & 2005 & leisure & 22 months \\
\hline 47 & $\begin{array}{l}\text { Advanced rock-climbing lessons banned after pupil's } 4 \mathrm{~m} \text { fall. } \\
\text { (FALL FROM HEIGHT) }\end{array}$ & $\begin{array}{l}\text { The Safety \& Health } \\
\text { Practitioner, July, 2013, } \\
\text { Vol.31(7), p.12(1) }\end{array}$ & 2013 & leisure & \\
\hline 48 & $\begin{array}{l}\text { Construction co failed to plan or monitor renovation project. } \\
\text { (FALL FROM HEIGHT) }\end{array}$ & $\begin{array}{l}\text { The Safety \& Health } \\
\text { Practitioner, March, 2013, } \\
\text { Vol.31(3), p.14(1) }\end{array}$ & 2013 & construction & \\
\hline 49 & $\begin{array}{l}\text { Fall from height: contractor hit with [pounds sterling] 150,000 } \\
\text { penalty for work-at-height deficiencies }\end{array}$ & $\begin{array}{l}\text { The Safety \& Health } \\
\text { Practitioner, Feb, 2005, } \\
\text { Vol.23(2), p.16(1) }\end{array}$ & 2005 & construction & 54 \\
\hline 50 & Fall from height: 'loose' sub-contracting in sewerage death case & $\begin{array}{l}\text { The Safety \& Health } \\
\text { Practitioner, Dec, 2006, } \\
\text { Vol.24(12), p.11(1) }\end{array}$ & 2006 & $\begin{array}{l}\text { sewage } \\
\text { maintenance }\end{array}$ & 51 \\
\hline 51 & Fall from height: worker needed facial reconstruction after fall & $\begin{array}{l}\text { The Safety \& Health } \\
\text { Practitioner, Feb, 2006, } \\
\text { Vol.24(2), p.14(1) }\end{array}$ & 2006 & construction & \\
\hline 52 & $\begin{array}{l}\text { No alternative available to dangerous lifting practice. } \\
\text { (FALL FROM HEIGHT) }\end{array}$ & $\begin{array}{l}\text { The Safety \& Health } \\
\text { Practitioner, August, } \\
2009 \text {, Vol.27(8), p.18(1) }\end{array}$ & 2009 & unspecified & \\
\hline 53 & Fall from height: fatal fall was easily preventable & $\begin{array}{l}\text { The Safety \& Health } \\
\text { Practitioner, Nov, 2006, } \\
\text { Vol.24(11), p.14(1) }\end{array}$ & 2006 & storehouse & 62 \\
\hline 54 & Fall from height: scaffolding boards were not properly supported & $\begin{array}{l}\text { The Safety \& Health } \\
\text { Practitioner, July, 2005, } \\
\text { Vol.23(7), p.16(1) }\end{array}$ & 2005 & construction & \\
\hline 55 & Fall from height: airline caterer fined over "very serious" incident & $\begin{array}{l}\text { The Safety \& Health } \\
\text { Practitioner, Oct, 2006, } \\
\text { Vol.24(10), p.16(1) }\end{array}$ & 2006 & airline & \\
\hline 56 & Fall from height: fines follow fatal fall from defective ladder & $\begin{array}{l}\text { The Safety \& Health } \\
\text { Practitioner, Sept, 2005, } \\
\text { Vol.23(9), p.17(1) }\end{array}$ & 2005 & $\begin{array}{l}\text { electrical } \\
\text { company }\end{array}$ & \\
\hline 57 & Fall from height: firms pay high price for scaffolding collapse & $\begin{array}{l}\text { The Safety \& Health } \\
\text { Practitioner, Dec, 2006, } \\
\text { Vol.24(12), p.12(1) }\end{array}$ & 2006 & construction & \\
\hline 58 & Fall from height: roof fall leaves worker in wheelchair & $\begin{array}{l}\text { The Safety \& Health } \\
\text { Practitioner, August, } \\
\text { 2005, Vol.23(8), p.14(1) }\end{array}$ & 2005 & agriculture & \\
\hline 59 & $\begin{array}{l}\text { Lack of edge protection led to fatal scaffold fall. } \\
\text { (FALL FROM HEIGHT) }\end{array}$ & $\begin{array}{l}\text { The Safety \& Health } \\
\text { Practitioner, Oct, 2009, } \\
\text { Vol.27(10), p.16(1) }\end{array}$ & 2009 & construction & \\
\hline 60 & $\begin{array}{l}\text { Boss tried to blame brother who sub-contracted him for demolition } \\
\text { job. (FALL FROM HEIGHT) }\end{array}$ & $\begin{array}{l}\text { The Safety \& Health } \\
\text { Practitioner, Sept, 2010, } \\
\text { Vol.28(9), p.12(1) }\end{array}$ & 2010 & construction & \\
\hline 61 & Crane fall leaves worker fighting for life. (FALL FROM HEIGHT) & $\begin{array}{l}\text { The Safety \& Health } \\
\text { Practitioner, June, 2009, } \\
\text { Vol.27(6), p.11(1) }\end{array}$ & 2009 & construction & 41 \\
\hline
\end{tabular}


Table 1A. Continued...

\begin{tabular}{|c|c|c|c|c|c|}
\hline $\mathbf{N r}$ & Title & Reference & $\begin{array}{l}\text { Fall } \\
\text { year }\end{array}$ & $\begin{array}{l}\text { type of } \\
\text { industry }\end{array}$ & $\begin{array}{l}\text { age of injured } \\
\text { worker (yrs) }\end{array}$ \\
\hline 62 & Fall from height: Earls Court fined for poor safety procedures & $\begin{array}{l}\text { The Safety \& Health } \\
\text { Practitioner, Feb, 2007, } \\
\text { Vol.25(2), p.14(1) }\end{array}$ & 2007 & $\begin{array}{l}\text { exhibition } \\
\text { center }\end{array}$ & \\
\hline 63 & $\begin{array}{l}\text { Fall from height: edge protection was not installed for farm roof } \\
\text { work }\end{array}$ & $\begin{array}{l}\text { The Safety \& Health } \\
\text { Practitioner, Feb, 2006, } \\
\text { Vol.24(2), p.16(1) }\end{array}$ & 2006 & construction & \\
\hline 64 & Fall from height: firm owner's friend died in roof fall & $\begin{array}{l}\text { The Safety \& Health } \\
\text { Practitioner, Sept, 2006, } \\
\text { Vol.24(9), p.16(1) }\end{array}$ & 2006 & construction & \\
\hline 65 & Fall from height: fragile roof was "totally unprotected" & $\begin{array}{l}\text { The Safety \& Health } \\
\text { Practitioner, March, 2008, } \\
\text { Vol.26(3), p.16(1) }\end{array}$ & 2008 & construction & 62 \\
\hline 66 & Fall from height: lack of edge protection led to fall & $\begin{array}{l}\text { The Safety \& Health } \\
\text { Practitioner, Nov, 2012, } \\
\text { Vol.30(11), p.11(1) }\end{array}$ & 2012 & construction & \\
\hline 67 & Fall from height: next employee died during training exercise & $\begin{array}{l}\text { The Safety \& Health } \\
\text { Practitioner, August, } \\
\text { 2005, Vol.23(8), p.14(1) }\end{array}$ & 2005 & warehouse & \\
\hline 68 & $\begin{array}{l}\text { Fall from height: young worker blacked out and fell through } \\
\text { unguarded lift well }\end{array}$ & $\begin{array}{l}\text { The Safety \& Health } \\
\text { Practitioner, March, 2007, } \\
\text { Vol.25(3), p.14(1) }\end{array}$ & 2007 & construction & 16 \\
\hline 69 & $\begin{array}{l}\text { Foam firm fined for second time in a fortnight. } \\
\text { (FALL FROM HEIGHT) }\end{array}$ & $\begin{array}{l}\text { The Safety \& Health } \\
\text { Practitioner, Jan, 2011, } \\
\text { Vol.29(1), p.12(1) }\end{array}$ & 2011 & construction & \\
\hline 70 & $\begin{array}{l}\text { lack of edge protection led to contractor fall. } \\
\text { (FALL FROM HEIGHT) }\end{array}$ & $\begin{array}{l}\text { The Safety \& Health } \\
\text { Practitioner, Nov, 2012, } \\
\text { Vol.30(11), p.11(1) }\end{array}$ & 2012 & construction & \\
\hline 71 & Fall from height: scaffolding fall costs two Welsh businesses & $\begin{array}{l}\text { The Safety \& Health } \\
\text { Practitioner, July, 2006, } \\
\text { Vol.24(7), p.14(1) }\end{array}$ & 2006 & construction & \\
\hline 72 & Fall-prevention measures didn’t work. (FALL FROM HEIGHT) & $\begin{array}{l}\text { The Safety \& Health } \\
\text { Practitioner, Jan, 2012, } \\
\text { Vol.30(1), p.16(1) }\end{array}$ & 2012 & construction & \\
\hline 73 & Firm failed to discharge its duties as construction client & $\begin{array}{l}\text { The Safety \& Health } \\
\text { Practitioner, March, 2010, } \\
\text { Vol.28(3), p.12(1) }\end{array}$ & 2010 & construction & \\
\hline 74 & Firms fined [pounds sterling]400k in scaffold-death case & $\begin{array}{l}\text { The Safety \& Health } \\
\text { Practitioner, May, 2011, } \\
\text { Vol.29(5), p.11(1) }\end{array}$ & 2011 & construction & \\
\hline 75 & Fall from height: roofer death lands building boss in jail & $\begin{array}{l}\text { The Safety \& Health } \\
\text { Practitioner, Feb, 2005, } \\
\text { Vol.23(2), p.11(1) }\end{array}$ & 2005 & construction & \\
\hline 76 & $\begin{array}{l}\text { "Shambolic" system of work cost scaffolder his life. } \\
\text { (FALL FROM HEIGHT) }\end{array}$ & $\begin{array}{l}\text { The Safety \& Health } \\
\text { Practitioner, Nov, 2004, } \\
\text { Vol.22(11), p.16(1) }\end{array}$ & 2004 & construction & \\
\hline 77 & $\begin{array}{l}\text { Director failed to recognise risks posed by fragile roof. } \\
\text { (FALL FROM HEIGHT) }\end{array}$ & $\begin{array}{l}\text { The Safety \& Health } \\
\text { Practitioner, Nov, 2009, } \\
\text { Vol.27(11), p.12(1) }\end{array}$ & 2009 & construction & 28 \\
\hline 78 & Fall from height: workers told to use ladder for fragile roof job & $\begin{array}{l}\text { The Safety \& Health } \\
\text { Practitioner, March, 2007, } \\
\text { Vol.25(3), p.12(1) }\end{array}$ & 2007 & construction & \\
\hline 79 & $\begin{array}{l}\text { Maintenance contractor fell from unsecured makeshift platform. } \\
\text { (FALL FROM HEIGHT) }\end{array}$ & $\begin{array}{l}\text { The Safety \& Health } \\
\text { Practitioner, Dec, 2012, } \\
\text { Vol.30(12), p.12(1) }\end{array}$ & 2012 & maintenance & 34 \\
\hline 80 & $\begin{array}{l}\text { Fall from height: boss tried to deceive investigators after fatal roof } \\
\text { fall }\end{array}$ & $\begin{array}{l}\text { The Safety \& Health } \\
\text { Practitioner, Jan, 2008, } \\
\text { Vol.26(1), p.13(1) }\end{array}$ & 2008 & construction & \\
\hline 81 & $\begin{array}{l}\text { Fall from height: companies to pay [pounds sterling] } 125 \mathrm{k} \text { after } \\
\text { worker is paralysed }\end{array}$ & $\begin{array}{l}\text { The Safety \& Health } \\
\text { Practitioner, April, 2005, } \\
\text { Vol.23(4), p.20(1) }\end{array}$ & 2005 & construction & \\
\hline 82 & Fall from height: company's "eyes were opened” by fall case & $\begin{array}{l}\text { The Safety \& Health } \\
\text { Practitioner, Sept, 2006, } \\
\text { Vol.24(9), p.18(1) }\end{array}$ & 2006 & maintenance & 19 \\
\hline 83 & $\begin{array}{l}\text { Fall from height: construction boss jailed for failing to provide safe } \\
\text { equipment for working at height }\end{array}$ & $\begin{array}{l}\text { The Safety \& Health } \\
\text { Practitioner, March, 2006, } \\
\text { Vol.24(3), p.11(1) }\end{array}$ & 2006 & construction & $\begin{array}{l}\text { worker } 1(40) \text {, } \\
\text { worker } 2(21)\end{array}$ \\
\hline
\end{tabular}


Table 1A. Continued...

\begin{tabular}{|c|c|c|c|c|c|}
\hline $\mathrm{Nr}$ & Title & Reference & $\begin{array}{l}\text { Fall } \\
\text { year }\end{array}$ & $\begin{array}{l}\text { type of } \\
\text { industry }\end{array}$ & $\begin{array}{l}\text { age of injured } \\
\text { worker (yrs) }\end{array}$ \\
\hline 84 & $\begin{array}{l}\text { Fall from height: construction boss jailed for failing to provide safe } \\
\text { equipment for working at height }\end{array}$ & $\begin{array}{l}\text { The Safety \& Health } \\
\text { Practitioner, March, 2006, } \\
\text { Vol.24(3), p.11(1) }\end{array}$ & 2006 & construction & $\begin{array}{l}\text { worker } 1(40) \text {, } \\
\text { worker } 2(21)\end{array}$ \\
\hline 85 & Fall from height: ladder did not provide safe access to crane & $\begin{array}{l}\text { The Safety \& Health } \\
\text { Practitioner, April, 2005, } \\
\text { Vol.23(4), p.22(1) }\end{array}$ & 2005 & foundry & \\
\hline 86 & $\begin{array}{l}\text { Fall from height: lack of planning led to fall from height fatality } \\
\text { on farm }\end{array}$ & $\begin{array}{l}\text { The Safety \& Health } \\
\text { Practitioner, August, } \\
\text { 2007, Vol.25(8), p.14(1) }\end{array}$ & 2007 & agriculture & \\
\hline 87 & Fall from height: no method statements in roof fall & $\begin{array}{l}\text { The Safety \& Health } \\
\text { Practitioner, Feb, 2007, } \\
\text { Vol.25(2), p.11(1) }\end{array}$ & 2007 & construction & \\
\hline 88 & Fall from height: roofer injured in eight-metre fall & $\begin{array}{l}\text { The Safety \& Health } \\
\text { Practitioner, July, 2006, } \\
\text { Vol.24(7), p.12(1) }\end{array}$ & 2006 & construction & 23 \\
\hline 89 & $\begin{array}{l}\text { Architects and building firm both at fault in fatal-fall case. } \\
\text { (FALL FROM HEIGHT) }\end{array}$ & $\begin{array}{l}\text { The Safety \& Health } \\
\text { Practitioner, Sept, 2010, } \\
\text { Vol.28(9), p.14(1) }\end{array}$ & 2010 & construction & \\
\hline 90 & $\begin{array}{l}\text { Fall from height/lifting: worker fell to his death during complicated } \\
\text { lifting operation }\end{array}$ & $\begin{array}{l}\text { The Safety \& Health } \\
\text { Practitioner, Feb, 2005, } \\
\text { Vol.23(2), p.15(1) }\end{array}$ & 2005 & construction & \\
\hline 91 & $\begin{array}{l}\text { Fall from height: unguarded hole cost worker his life and property } \\
\text { owners [pounds sterling] } 120,000\end{array}$ & $\begin{array}{l}\text { The Safety \& Health } \\
\text { Practitioner, June, 2005, } \\
\text { Vol.23(6), p.14(1) }\end{array}$ & 2005 & construction & 37 \\
\hline 92 & Fall from height: practice of hand-winding lift ends in disaster & $\begin{array}{l}\text { The Safety \& Health } \\
\text { Practitioner, Jan, 2007, } \\
\text { Vol.25(1), p.12(1) }\end{array}$ & 2007 & unspecified & \\
\hline 93 & Fall from height: rooflight plunge costs contractor & $\begin{array}{l}\text { The Safety \& Health } \\
\text { Practitioner, Dec, 2004, } \\
\text { Vol.22(12), p.18(1) }\end{array}$ & 2004 & construction & \\
\hline 94 & Fall from height: three firms fined over bus garage plunge & $\begin{array}{l}\text { The Safety \& Health } \\
\text { Practitioner, Jan, 2006, } \\
\text { Vol.24(1), p.10(1) }\end{array}$ & 2006 & construction & \\
\hline 95 & $\begin{array}{l}\text { Firm that ignored HSE advice fined [pounds sterling] 145k. } \\
\text { (FALL FROM HEIGHT) }\end{array}$ & $\begin{array}{l}\text { The Safety \& Health } \\
\text { Practitioner, Dec, 2011, } \\
\text { Vol.29(12), p.12(1) }\end{array}$ & 2011 & construction & \\
\hline 96 & $\begin{array}{l}\text { Miscommunication led to worker's stairwell plunge. } \\
\text { (FALL FROM HEIGHT) }\end{array}$ & $\begin{array}{l}\text { The Safety \& Health } \\
\text { Practitioner, August, } \\
2013 \text {, Vol.31(8), p.12(1) }\end{array}$ & 2013 & construction & 32 \\
\hline 97 & $\begin{array}{l}\text { Potentially fatal fall costs firms [pounds sterling] } 214 \mathrm{k} \text {. } \\
\text { (FALL FROM HEIGHT) }\end{array}$ & $\begin{array}{l}\text { The Safety \& Health } \\
\text { Practitioner, August, } \\
\text { 2009, Vol.27(8), p.18(1) }\end{array}$ & 2009 & unspecified & \\
\hline 98 & $\begin{array}{l}\text { Fall from height: death at second Edinburgh hotel leads to [pounds } \\
\text { sterling]400k fine }\end{array}$ & $\begin{array}{l}\text { The Safety \& Health } \\
\text { Practitioner, Dec, 2005, } \\
\text { Vol.23(12), p.14(1) }\end{array}$ & 2005 & hotel & \\
\hline 99 & $\begin{array}{l}\text { Fall from height: window ledge was not high enough to prevent } \\
\text { fatal fall }\end{array}$ & $\begin{array}{l}\text { The Safety \& Health } \\
\text { Practitioner, Jan, 2007, } \\
\text { Vol.25(1), p.12(1) }\end{array}$ & 2007 & construction & \\
\hline 100 & $\begin{array}{l}\text { Big fines for two firms over power-station death. } \\
\text { (FALL FROM HEIGHT) }\end{array}$ & $\begin{array}{l}\text { The Safety \& Health } \\
\text { Practitioner, July, 2011, } \\
\text { Vol.29(7), p.11(1) }\end{array}$ & 2011 & construction & \\
\hline 101 & $\begin{array}{l}\text { lgnorance of regulations is no excuse, firm told. } \\
\text { (FALL FROM HEIGHT) }\end{array}$ & $\begin{array}{l}\text { The Safety \& Health } \\
\text { Practitioner, August, } \\
\text { 2006, Vol.24(8), p.16(1) }\end{array}$ & 2006 & construction & \\
\hline 102 & Fall from height: sailor plummeted $12 \mathrm{ft}$ to his death on ship's deck & $\begin{array}{l}\text { The Safety \& Health } \\
\text { Practitioner, Nov, 2007, } \\
\text { Vol.25(11), p.14(1) }\end{array}$ & 2007 & $\begin{array}{l}\text { ship in a dry } \\
\text { dock }\end{array}$ & \\
\hline 103 & $\begin{array}{l}\text { Fall from height fatality results in [pounds sterling]75k fine for } \\
\text { major scaffolding firm }\end{array}$ & $\begin{array}{l}\text { The Safety \& Health } \\
\text { Practitioner, June, 2003, } \\
\text { Vol.21(6), p.6(1) }\end{array}$ & 2003 & construction & \\
\hline 104 & $\begin{array}{l}\text { Fatal fall during T5 project caused by faulty fixings. } \\
\text { (FALL FROM HEIGHT) }\end{array}$ & $\begin{array}{l}\text { The Safety \& Health } \\
\text { Practitioner, Dec, 2009, } \\
\text { Vol.27(12), p.15(1) }\end{array}$ & 2009 & construction & \\
\hline 105 & $\begin{array}{l}\text { Fatal fall during T5 project caused by faulty fixings. } \\
\text { (FALL FROM HEIGHT) }\end{array}$ & $\begin{array}{l}\text { The Safety \& Health } \\
\text { Practitioner, Dec, 2009, } \\
\text { Vol.27(12), p.15(1) }\end{array}$ & 2009 & construction & \\
\hline
\end{tabular}


Table 1A. Continued...

\begin{tabular}{|c|c|c|c|c|c|}
\hline $\mathrm{Nr}$ & Title & Reference & $\begin{array}{l}\text { Fall } \\
\text { year }\end{array}$ & $\begin{array}{l}\text { type of } \\
\text { industry }\end{array}$ & $\begin{array}{l}\text { age of injured } \\
\text { worker (yrs) }\end{array}$ \\
\hline 106 & $\begin{array}{l}\text { Carillion to pay [pound sterling]94K after young employee fell to } \\
\text { his death. (FALL FROM HEIGHT) }\end{array}$ & $\begin{array}{l}\text { The Safety \& Health } \\
\text { Practitioner, Sept, 2008, } \\
\text { Vol.26(9), p.16(1) }\end{array}$ & 2008 & construction & young \\
\hline 107 & Fall from height: three parties prosecuted over fatal fall & $\begin{array}{l}\text { The Safety \& Health } \\
\text { Practitioner, August, } \\
\text { 2005, Vol.23(8), p.12(1) }\end{array}$ & 2005 & construction & \\
\hline 108 & $\begin{array}{l}\text { Maintenance worker jailed for four years after toddler's death. } \\
\text { (FALL FROM HEIGHT) }\end{array}$ & $\begin{array}{l}\text { The Safety \& Health } \\
\text { Practitioner, March, 2014, } \\
\text { Vol.32(3), p.11(1) }\end{array}$ & 2014 & unspecified & 2 \\
\hline 109 & $\begin{array}{l}£ 42 \mathrm{k} \text { to pay following scaffolding death fall (same page as Fall } \\
\text { from height: ladder did not provide safe access to crane) }\end{array}$ & $\begin{array}{l}\text { The Safety \& Health } \\
\text { Practitioner, April, 2005, } \\
\text { Vol.23(4), p.22(1) }\end{array}$ & 2005 & construction & \\
\hline 110 & $\begin{array}{l}\text { Carillion fined [pounds sterling]130,000 for fatal fall. } \\
\text { (FALL FROM HEIGHT) }\end{array}$ & $\begin{array}{l}\text { The Safety \& Health } \\
\text { Practitioner, Jan, 2013, } \\
\text { Vol.31(1), p.12(1) }\end{array}$ & 2013 & construction & \\
\hline 111 & Massive fine for fatal fall in 2004. (FALL FROM HEIGHT) & $\begin{array}{l}\text { The Safety \& Health } \\
\text { Practitioner, August, } \\
\text { 2012, Vol.30(8), p.14(1) }\end{array}$ & 2012 & construction & \\
\hline 112 & $\begin{array}{l}\text { MD jailed for manslaughter of 20-year-old roof worker. } \\
\text { (FALL FROM HEIGHT) }\end{array}$ & $\begin{array}{l}\text { The Safety \& Health } \\
\text { Practitioner, March, 2009, } \\
\text { Vol.27(3), p.12(1) }\end{array}$ & 2009 & construction & 20 \\
\hline 113 & Fall from height: contractor died when staircase collapsed & $\begin{array}{l}\text { The Safety \& Health } \\
\text { Practitioner, May, 2006, } \\
\text { Vol.24(5), p.14(1) }\end{array}$ & 2006 & power station & \\
\hline 114 & $\begin{array}{l}\text { Fall from height: failure to maintain lifts costs firm [pounds } \\
\text { sterling]545,000 }\end{array}$ & $\begin{array}{l}\text { The Safety \& Health } \\
\text { Practitioner, May, 2006, } \\
\text { Vol.24(5), p.13(1) }\end{array}$ & 2006 & leisure & $\begin{array}{l}\text { worker } 1 \text { (27), } \\
\text { worker } 2 \text { (25) }\end{array}$ \\
\hline
\end{tabular}

Table 2A. Included articles, illustration of the falling height by articles, consequence, injured body parts and recovery period.

\begin{tabular}{|c|c|c|c|c|c|c|c|}
\hline $\mathrm{Nr}$ & $\begin{array}{l}\text { Height } \\
\text { (m) }\end{array}$ & $\begin{array}{l}\text { NOTHING } \\
\text { INJURED }\end{array}$ & $\begin{array}{l}\text { TEMPORARY } \\
\text { DISABILITY }\end{array}$ & $\begin{array}{l}\text { PERMANENT } \\
\text { DISABILITY }\end{array}$ & DEAD & $\begin{array}{l}\text { Injured body part as } \\
\text { described in articles }\end{array}$ & $\begin{array}{c}\text { Treatment/recovery/lost } \\
\text { working hours }\end{array}$ \\
\hline 1 & 1.2 & 0 & 1 & 0 & & injured his knee & \\
\hline 2 & 1.4 & 0 & 1 & 0 & & arm & $\begin{array}{l}\text { received treatment for a broken } \\
\text { arm, unable to return to work for } \\
\text { more than five months }\end{array}$ \\
\hline 3 & 1.4 & 0 & 1 & 0 & & $\begin{array}{l}\text { cut to his head, fractured } \\
\text { his right shoulder, and } \\
\text { sprained his ankle }\end{array}$ & \\
\hline 4 & 1.5 & 0 & 1 & 0 & & $\begin{array}{l}\text { breaking his collar-bone and } \\
\text { suffering concussion }\end{array}$ & \\
\hline 5 & 1.8 & 0 & 0 & 1 & 0 & $\begin{array}{l}\text { severe and lasting damage } \\
\text { to his back }\end{array}$ & \\
\hline 6 & 1.8 & 0 & 0 & 0 & 1 & fractured his skull & \\
\hline 7 & 1.9 & 0 & 1 & 0 & 0 & broke two ribs and one arm & $\begin{array}{l}\text { needed a three inch metal } \\
\text { plate and multiple metal screws } \\
\text { inserted into a broken arm }\end{array}$ \\
\hline 8 & 2 & 0 & 1 & 0 & 0 & $\begin{array}{l}\text { shattered left shoulder and } \\
\text { collarbone, several broken } \\
\text { ribs, a deep cut to his head }\end{array}$ & $\begin{array}{l}\text { he is unable to work owing } \\
\text { to his injuries and still suffer } \\
\text { considerable pain in his shoulder }\end{array}$ \\
\hline 9 & 2.2 & 0 & 1 & 0 & 0 & $\begin{array}{l}\text { worker } 2 \text { (bruised eye, cut } \\
\text { on the back of his head) }\end{array}$ & \\
\hline 10 & 2.2 & 0 & 1 & 0 & 0 & $\begin{array}{l}\text { worker } 1 \text { (broke his } \\
\text { collarbone) }\end{array}$ & $\begin{array}{l}\text { worker } 1 \text { (unable to return to } \\
\text { work for six weeks owing to his } \\
\text { injuries) }\end{array}$ \\
\hline 11 & 2.3 & 0 & 0 & 1 & 0 & $\begin{array}{l}\text { fractured vertebrae in her } \\
\text { back and has been left } \\
\text { permanently paralysed from } \\
\text { the waist down. }\end{array}$ & \\
\hline 12 & 2.3 & 0 & 1 & 0 & 0 & $\begin{array}{l}\text { one individual underwent } \\
\text { surgery to insert a metal rod } \\
\text { in her shinbone and screws } \\
\text { in both ankles, }\end{array}$ & \\
\hline
\end{tabular}


Table 2A. Continued...

\begin{tabular}{|c|c|c|c|c|c|c|c|}
\hline $\mathrm{Nr}$ & $\begin{array}{l}\text { Height } \\
\text { (m) }\end{array}$ & $\begin{array}{l}\text { NOTHING } \\
\text { INJURED }\end{array}$ & $\begin{array}{l}\text { TEMPORARY } \\
\text { DISABILITY }\end{array}$ & $\begin{array}{l}\text { PERMANENT } \\
\text { DISABILITY }\end{array}$ & DEAD & $\begin{array}{l}\text { Injured body part as } \\
\text { described in articles }\end{array}$ & $\begin{array}{l}\text { Treatment/recovery/lost } \\
\text { working hours }\end{array}$ \\
\hline 13 & 2.3 & 1 & 0 & 0 & 0 & $\begin{array}{l}\text { others suffered shock and } \\
\text { bruising }\end{array}$ & \\
\hline 14 & 2.5 & 0 & 1 & 0 & 0 & shattering his left heel bone & \\
\hline 15 & 2.5 & 0 & 0 & 1 & 0 & $\begin{array}{l}\text { punctured lung and spinal } \\
\text { fracture }\end{array}$ & \\
\hline 16 & 2.5 & 0 & 0 & 0 & 1 & severe head injuries & \\
\hline 17 & 2.7 & 0 & 1 & 0 & 0 & $\begin{array}{l}\text { damaged ligaments in his } \\
\text { left shoulder and a series of } \\
\text { cuts to his head }\end{array}$ & \\
\hline 18 & 2.7 & 0 & 1 & 0 & 0 & $\begin{array}{l}\text { fracturing a bone in his } \\
\text { skull }\end{array}$ & \\
\hline 19 & 2.7 & 0 & 0 & 1 & 0 & severe head injuries & $\begin{array}{l}\text { hospitalized for more than four } \\
\text { months. It is unlikely he will be } \\
\text { ever be able to return to work. }\end{array}$ \\
\hline 20 & 3 & 0 & 0 & 1 & 0 & broken spine & $\begin{array}{l}\text { had surgery to insert a metal disk } \\
\text { into his back }\end{array}$ \\
\hline 21 & 3 & 0 & 1 & 0 & 0 & $\begin{array}{l}\text { fractured neck, arm, } \\
\text { suffered soft tissue injuries } \\
\text { to his kidney and hip }\end{array}$ & several months on recovery \\
\hline 22 & 3 & 0 & 0 & 0 & 1 & multiple skull fractures & \\
\hline 23 & 3 & 1 & 0 & 0 & 0 & & \\
\hline 24 & 3 & 0 & 0 & 0 & 1 & in a coma for three months & \\
\hline 25 & 3 & 0 & 0 & 1 & 0 & $\begin{array}{l}\text { fractured skull, broke all } \\
\text { of the ribs on the left side } \\
\text { of his body, and suffered } \\
\text { spinal damage }\end{array}$ & \\
\hline 26 & 3 & 0 & 0 & 0 & 1 & & \\
\hline 27 & 3 & 0 & 1 & 0 & 0 & $\begin{array}{l}\text { fractured his right leg in } \\
\text { four places }\end{array}$ & off work for 10 months \\
\hline 28 & 3 & 0 & 0 & 1 & 0 & $\begin{array}{l}\text { permanently disabled, } \\
\text { serious spinal injuries, } \\
\text { internal injuries and cuts }\end{array}$ & $\begin{array}{l}\text { cant no longer work, suffers } \\
\text { constant pain and psychiatric } \\
\text { problems }\end{array}$ \\
\hline 29 & 3 & 0 & 0 & 0 & 1 & fatal head injuries & \\
\hline 30 & 3 & 0 & 1 & 0 & 0 & 1) no serious injuries & \\
\hline 31 & 3 & 0 & 0 & 1 & 0 & severe spinal injuries & \\
\hline 32 & 3 & 0 & 1 & 0 & 0 & $\begin{array}{l}\text { multiple injuries, including } \\
\text { fractures to his vertebrae, } \\
\text { ribs and wrist }\end{array}$ & \\
\hline 33 & 3 & 1 & 0 & 0 & 0 & minor burns and blisters & \\
\hline 34 & 3 & 0 & 1 & 0 & 0 & $\begin{array}{l}4 \text { workers suffered spinal } \\
\text { fractures, broken shoulders, } \\
\text { and fractured ribs }\end{array}$ & \\
\hline
\end{tabular}

lost consciousness for

several minutes after

his head hit the ground,

suffered severe headaches and a paintful swelling to his head,

\begin{tabular}{|c|c|c|c|c|c|c|c|}
\hline 35 & 3 & 0 & 1 & 0 & 0 & $\begin{array}{l}\text { suffered severe headaches } \\
\text { and a paintful swelling to } \\
\text { his head, }\end{array}$ & $\begin{array}{l}\text { unable to work for some time } \\
\text { afterwards }\end{array}$ \\
\hline 36 & 3 & 0 & 1 & 0 & 0 & $\begin{array}{l}\text { breaking his shoulder and } \\
\text { several ribs }\end{array}$ & off work for two months \\
\hline 37 & 3 & 0 & 1 & 0 & 0 & broke his ankle & \\
\hline 38 & 3 & 0 & 1 & 0 & 0 & $\begin{array}{l}\text { dislocating fingers on his } \\
\text { left hand, breaking his left } \\
\text { wrist, fracturing vertebrae } \\
\text { in his neck }\end{array}$ & $\begin{array}{l}\text { kept in hospital for } 5 \text { days and } \\
\text { had to wear a neck brace for } \\
\text { three months }\end{array}$ \\
\hline 39 & 3.3 & 0 & 1 & 0 & 0 & major injuries & \\
\hline 40 & 3.4 & 0 & 0 & 1 & 0 & serious spinal injury & \\
\hline 41 & 3.4 & 0 & 1 & 0 & 0 & shattered his ankle & \\
\hline 42 & 3.5 & 0 & 1 & 0 & 0 & $\begin{array}{l}\text { crushed vertebra and } \\
\text { fractured pelvis }\end{array}$ & \\
\hline 43 & 3.6 & 0 & 1 & 0 & 0 & serious injuries & \\
\hline
\end{tabular}

unable to work for some time afterwards 
Table 2A. Continued...

\begin{tabular}{|c|c|c|c|c|c|c|c|}
\hline $\mathrm{Nr}$ & $\begin{array}{l}\text { Height } \\
\text { (m) }\end{array}$ & $\begin{array}{l}\text { NOTHING } \\
\text { INJURED }\end{array}$ & $\begin{array}{l}\text { TEMPORARY } \\
\text { DISABILITY }\end{array}$ & $\begin{array}{l}\text { PERMANENT } \\
\text { DISABILITY }\end{array}$ & DEAD & $\begin{array}{l}\text { Injured body part as } \\
\text { described in articles }\end{array}$ & $\begin{array}{c}\text { Treatment/recovery/lost } \\
\text { working hours }\end{array}$ \\
\hline 44 & 3.6 & 0 & 0 & 1 & 0 & $\begin{array}{l}\text { paralysed from the waist } \\
\text { down }\end{array}$ & \\
\hline 45 & 3.7 & 0 & 1 & 0 & 0 & $\begin{array}{l}8 \text { broken ribs, broken } \\
\text { collarbone and life } \\
\text { threatening internal injuries }\end{array}$ & \\
\hline 46 & 3.7 & 0 & 1 & 0 & 0 & fractured skull & \\
\hline 47 & 4 & 0 & 1 & 0 & 0 & fractured heel bone & \\
\hline 48 & 4 & 0 & 1 & 0 & 0 & $\begin{array}{l}\text { two fractured vertebrae and } \\
\text { five broken ribs }\end{array}$ & \\
\hline 49 & 4 & 0 & 0 & 0 & 1 & $\begin{array}{l}\text { suffering severe head } \\
\text { injuries }\end{array}$ & \\
\hline 50 & 5 & 0 & 0 & 0 & 1 & & \\
\hline 51 & 4 & 0 & 1 & 0 & 0 & $\begin{array}{l}\text { broken pelvis, four fractured } \\
\text { ribs and a damaged spleen, } \\
\text { as well as the facial injuries. }\end{array}$ & $\begin{array}{l}\text { metal plates inserted in his } \\
\text { mouth, jaw, nose, and eye } \\
\text { sockets }\end{array}$ \\
\hline 52 & 4 & 0 & 1 & 0 & 0 & fractured his leg and ankle & \\
\hline 53 & 4.6 & 0 & 0 & 0 & 1 & multiple injuries & \\
\hline 54 & 4.8 & 0 & 0 & 1 & 0 & paralysed below the waist & \\
\hline 55 & 5 & 0 & 1 & 0 & 0 & $\begin{array}{l}\text { broken right leg, broken } \\
\text { femur in his left leg, and } \\
\text { cuts and bruising }\end{array}$ & \\
\hline 56 & 5 & 0 & 0 & 0 & 1 & fatally injured & \\
\hline 57 & 5 & 0 & 1 & 0 & 0 & $\begin{array}{l}\text { suffered a severe head } \\
\text { laceration, broken wrist, and } \\
\text { a broken rib }\end{array}$ & \\
\hline 58 & 5 & 0 & 1 & 0 & 0 & $\begin{array}{l}\text { multiple broken bones and } \\
\text { head injuries }\end{array}$ & long recovery, still in wheelchair \\
\hline 59 & 5 & 0 & 0 & 0 & 1 & serious head injuries & \\
\hline 60 & 6 & 0 & 0 & 1 & 0 & $\begin{array}{l}16 \text { skull fractures, damaging } \\
\text { parts of the brain, removed } \\
\text { parts of the brain, broken } \\
\text { jaw in three places, deaf in } \\
\text { his right ear and blind in his } \\
\text { left eye. }\end{array}$ & \\
\hline 61 & 6 & 0 & 1 & 0 & 0 & $\begin{array}{l}\text { multiple fractures to his } \\
\text { skull, a broken collarbone, } \\
\text { several broken ribs, and } \\
\text { swelling to his brain }\end{array}$ & $\begin{array}{l}\text { discharged from hospital after } \\
\text { five weeks but has been unable } \\
\text { to return to work owing to the } \\
\text { severity of his injuries }\end{array}$ \\
\hline 62 & 6 & 0 & 1 & 0 & 0 & $\begin{array}{l}\text { punctured lungs, broken } \\
\text { ribs, broken limbs, bleeding } \\
\text { on the brain }\end{array}$ & three weeks in intensive care \\
\hline 63 & 6 & 0 & 1 & 0 & 0 & serious injuries & \\
\hline 64 & 6 & 0 & 0 & 0 & 1 & & \\
\hline 65 & 6 & 0 & 0 & 0 & 1 & fatal injuries & \\
\hline 66 & 6 & 1 & 0 & 0 & 0 & cuts on his head & \\
\hline 67 & 6 & 0 & 0 & 0 & 1 & head injuries & \\
\hline 68 & 6 & 0 & 1 & 0 & 0 & $\begin{array}{l}\text { suffered fractured skull, } \\
\text { brain haemorrhage, facial } \\
\text { and leg injuries, and } \\
\text { extensive bruising }\end{array}$ & \\
\hline 69 & 6 & 0 & 1 & 0 & 0 & suffered tissue damage & off work for 6 weeks \\
\hline 70 & 6 & 0 & 0 & 0 & 1 & serious head injuries & $\begin{array}{l}\text { several months in hospital with } \\
\text { gradual recovery, however the } \\
\text { brain injury he suffered exposed } \\
\text { him to a much higher degree of } \\
\text { infection }\end{array}$ \\
\hline 71 & 6.1 & 0 & 1 & 0 & 0 & $\begin{array}{l}\text { sustained double fracture of } \\
\text { the pelvis, fractured elbow } \\
\text { and head lacerations }\end{array}$ & \\
\hline 72 & 6.5 & 0 & 1 & 0 & 0 & $\begin{array}{l}\text { suffered fractures to his } \\
\text { spine, skull and ribs }\end{array}$ & $\begin{array}{l}\text { unable to return to work owing } \\
\text { to his injuries }\end{array}$ \\
\hline 73 & 6.5 & 0 & 1 & 0 & 0 & $\begin{array}{l}\text { two fractured vertebrae and } \\
\text { serious injuries to his hands. }\end{array}$ & \\
\hline
\end{tabular}


Table 2A. Continued...

\begin{tabular}{|c|c|c|c|c|c|c|c|}
\hline $\mathrm{Nr}$ & $\begin{array}{l}\text { Height } \\
\text { (m) }\end{array}$ & $\begin{array}{l}\text { NOTHING } \\
\text { INJURED }\end{array}$ & $\begin{array}{l}\text { TEMPORARY } \\
\text { DISABILITY }\end{array}$ & $\begin{array}{l}\text { PERMANENT } \\
\text { DISABILITY }\end{array}$ & DEAD & $\begin{array}{l}\text { lnjured body part as } \\
\text { described in articles }\end{array}$ & $\begin{array}{c}\text { Treatment/recovery/lost } \\
\text { working hours }\end{array}$ \\
\hline 74 & 6.5 & 0 & 0 & 0 & 1 & serious head injuries & \\
\hline 75 & 6.75 & 0 & 0 & 0 & 1 & fatal injuries & \\
\hline 76 & 7 & 0 & 0 & 0 & 1 & & \\
\hline 77 & 7 & 0 & 0 & 1 & 0 & $\begin{array}{l}\text { fractures to his skull, pelvis, } \\
\text { wrist, and right cheekbone, } \\
\text { permanent damage to the } \\
\text { optical nerve in his right eye }\end{array}$ & \\
\hline 78 & 7 & 0 & 1 & 0 & 0 & $\begin{array}{l}\text { broke both his wrists, } \\
\text { his ankle, his lef elbow, } \\
\text { sustained a fractured skull } \\
\text { with bleeding on the brain, } \\
\text { and lost four teeth }\end{array}$ & \\
\hline 79 & 7 & 0 & 0 & 1 & 0 & $\begin{array}{l}\text { multiple fractures to his } \\
\text { skull, leg, back, wrist }\end{array}$ & $\begin{array}{l}\text { spent } 10 \text { days in hospital and } \\
\text { remains on crutches. It is still } \\
\text { unclear if he will ever be able to } \\
\text { return to work. }\end{array}$ \\
\hline 80 & 7.6 & 0 & 0 & 0 & 1 & serious injuries & $\begin{array}{l}\text { required surgery for a broken } \\
\text { collar bone, after operation } \\
\text { suffered a pulmonary fat } \\
\text { embolism caused by his injuries }\end{array}$ \\
\hline 81 & 7.6 & 0 & 0 & 1 & 0 & $\begin{array}{l}\text { in coma for } 6 \text { weeks, now } \\
\text { paralysed and confined to a } \\
\text { wheelchair }\end{array}$ & \\
\hline 82 & 7.6 & 0 & 1 & 0 & 0 & 50 broken bones & \\
\hline 83 & 7.6 & 0 & 1 & 0 & 0 & $\begin{array}{l}\text { worker } 2 \text { (sustained a } \\
\text { serious leg injury) }\end{array}$ & \\
\hline 84 & 7.6 & 0 & 0 & 0 & 1 & worker 1 (died) & \\
\hline 85 & 7.6 & 0 & 1 & 0 & 0 & $\begin{array}{l}\text { suffering head injuries and } \\
\text { a fractured pelvis }\end{array}$ & \\
\hline 86 & 8 & 0 & 0 & 0 & 1 & & \\
\hline 87 & 8 & 0 & 0 & 0 & 1 & & \\
\hline 88 & 8 & 0 & 1 & 0 & 0 & $\begin{array}{l}\text { fractured jaw and } \\
\text { substantial soft tissue } \\
\text { injuries to his body and face }\end{array}$ & \\
\hline 89 & 9 & 0 & 0 & 0 & 1 & & \\
\hline 90 & 9 & 0 & 0 & 0 & 1 & & \\
\hline 91 & 9 & 0 & 0 & 0 & 1 & & \\
\hline 92 & 9.1 & 0 & 1 & 0 & 0 & $\begin{array}{l}\text { severed her leg and broke } \\
\text { her ankle }\end{array}$ & \\
\hline 93 & 10 & 0 & 1 & 0 & 0 & $\begin{array}{l}\text { injuries to his pelvis, back, } \\
\text { heel bone and elbow }\end{array}$ & \\
\hline 94 & 10 & 0 & 1 & 0 & 0 & $\begin{array}{l}\text { serious injuries to his arms } \\
\text { and pelvis, severely brushing } \\
\text { his heart, and suffering a } \\
\text { collapsed lung. }\end{array}$ & $\begin{array}{l}\text { remained on a life support } \\
\text { machine for ten days }\end{array}$ \\
\hline 95 & 10 & 0 & 0 & 0 & 1 & $\begin{array}{l}\text { fractured skull and } \\
\text { developed post-traumatic } \\
\text { epilepsy as a result of his } \\
\text { injuries }\end{array}$ & \\
\hline 96 & 10 & 0 & 0 & 1 & 0 & $\begin{array}{l}\text { shattered right elbow, } \\
\text { broken vertebrae, fractured } \\
\text { pelvis, and ribs, and damage } \\
\text { to internal organs. }\end{array}$ & $\begin{array}{l}\text { he was unable to return to work } \\
\text { for two years and can no longer } \\
\text { work in construction }\end{array}$ \\
\hline 97 & 10 & 0 & 1 & 0 & 0 & serious injuries & \\
\hline 98 & 10.7 & 0 & 0 & 0 & 1 & & \\
\hline 99 & 11 & 0 & 0 & 0 & 1 & & \\
\hline 100 & 12 & 0 & 0 & 0 & 1 & fatal chest injuries & \\
\hline 101 & 3 & 1 & 0 & 0 & 0 & & \\
\hline 102 & 12 & 0 & 0 & 0 & 1 & & \\
\hline 103 & 13 & 0 & 0 & 0 & 1 & & \\
\hline
\end{tabular}


Table 2A. Continued...

\begin{tabular}{|c|c|c|c|c|c|c|c|}
\hline $\mathrm{Nr}$ & $\begin{array}{l}\text { Height } \\
(\mathrm{m})\end{array}$ & $\begin{array}{l}\text { NOTHING } \\
\text { INJURED }\end{array}$ & $\begin{array}{l}\text { TEMPORARY } \\
\text { DISABILITY }\end{array}$ & $\begin{array}{l}\text { PERMANENT } \\
\text { DISABILITY }\end{array}$ & DEAD & $\begin{array}{l}\text { Injured body part as } \\
\text { described in articles }\end{array}$ & $\begin{array}{c}\text { Treatment/recovery/lost } \\
\text { working hours }\end{array}$ \\
\hline 104 & 15.24 & 0 & 0 & 1 & 0 & $\begin{array}{l}\text { 2) multiple serious injuries, } \\
\text { including fractures to his } \\
\text { back, leg and jaw }\end{array}$ & \\
\hline 105 & 15.24 & 0 & 0 & 0 & 1 & & \\
\hline 106 & 17 & 0 & 0 & 0 & 1 & & \\
\hline 107 & 17,5 & 0 & 0 & 0 & 1 & & \\
\hline 108 & 18 & 0 & 0 & 0 & 1 & & \\
\hline 109 & 18.3 & 0 & 0 & 0 & 1 & & \\
\hline 110 & 19 & 0 & 0 & 0 & 1 & & \\
\hline 111 & 22 & 0 & 0 & 0 & 1 & & \\
\hline 112 & 25 & 0 & 0 & 0 & 1 & head injuries & \\
\hline 113 & 30 & 0 & 0 & 0 & 1 & & \\
\hline 114 & 42 & 0 & 0 & 0 & 1 & & \\
\hline
\end{tabular}

Table 3A. Included articles, illustration of the measures which were Not Appropriate (NA), were missing (0) or should be Additionally (A) considered among each one of included cases.

\begin{tabular}{|c|c|c|c|c|c|c|c|c|c|c|c|}
\hline $\mathrm{Nr}$ & 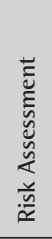 & 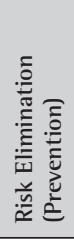 & 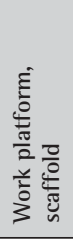 & $\begin{array}{l}\frac{\bar{z}}{\frac{0}{0}} \\
\frac{\pi}{0} \\
\frac{\tilde{\nu}}{n}\end{array}$ & 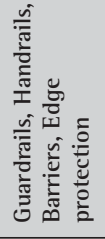 & 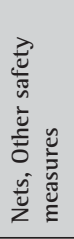 & 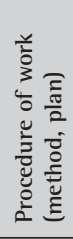 & 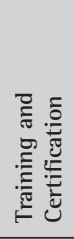 & 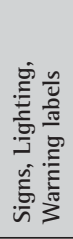 & 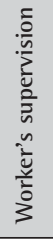 & 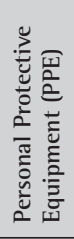 \\
\hline 1 & & & & NA & & & A & A & & A & \\
\hline 2 & $\mathrm{~A}$ & & 0 & & 0 & & A & & & $\mathrm{A}$ & \\
\hline 3 & 0 & 0 & & & 0 & & A & & 0 & A & \\
\hline 4 & NA & & & NA & & & NA & A & & A & \\
\hline 5 & NA & & & & & & A & NA & & A & \\
\hline 6 & NA & & & NA & & & 0 & 0 & & 0 & \\
\hline 7 & 0 & & 0 & & 0 & & $\mathrm{NA}$ & 0 & & 0 & \\
\hline 8 & & & 0 & NA & 0 & & & & & & \\
\hline 9 & NA & & 0 & & 0 & & A & & & $\mathrm{A}$ & \\
\hline 10 & NA & & 0 & & 0 & & A & & & $\mathrm{A}$ & \\
\hline 11 & & 0 & & & 0 & & & & 0 & & \\
\hline 12 & A & & & & 0 & & & & & & \\
\hline 13 & A & & & & 0 & & & & & & \\
\hline 14 & A & 0 & & & & & NA & & & & \\
\hline 15 & & 0 & & & 0 & A & & & A & & \\
\hline 16 & & & NA & NA & NA & & & & & & A \\
\hline 17 & & & NA & & NA & & & & & $\mathrm{A}$ & $\mathrm{A}$ \\
\hline 18 & & 0 & & & NA & A & & & A & & \\
\hline 19 & & 0 & & & 0 & 0 & & & A & & \\
\hline 20 & A & & 0 & & 0 & A & A & & & & A \\
\hline 21 & A & & A & & A & 0 & A & & & & A \\
\hline 22 & 0 & & & & NA & A & A & & & & A \\
\hline \multicolumn{12}{|l|}{23} \\
\hline 24 & & & NA & & $\mathrm{NA}$ & & & & & & \\
\hline 25 & $\mathrm{NA}$ & & 0 & & 0 & & NA & & & $\mathrm{A}$ & A \\
\hline 26 & NA & & NA & & & & A & 0 & & & A \\
\hline 27 & 0 & & A & & & & 0 & 0 & & 0 & \\
\hline 28 & & & & $\mathrm{NA}$ & & & & A & & & \\
\hline 29 & 0 & & & A & & & 0 & 0 & & $\mathrm{~A}$ & \\
\hline 30 & & & NA & A & & & NA & & & NA & \\
\hline 31 & & & NA & & & & A & & & & A \\
\hline 32 & & & NA & & $\mathrm{NA}$ & & A & 0 & & 0 & 0 \\
\hline 33 & & 0 & & & 0 & & & & & & \\
\hline 34 & & & NA & & 0 & & NA & 0 & A & A & \\
\hline 35 & 0 & & 0 & 0 & & & A & & & $\mathrm{A}$ & A \\
\hline 36 & NA & & A & & & A & & & & NA & 0 \\
\hline
\end{tabular}


Table 3A. Continued...

\begin{tabular}{|c|c|c|c|c|c|c|c|c|c|c|c|}
\hline $\mathrm{Nr}$ & 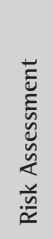 & 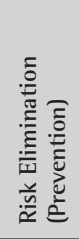 & 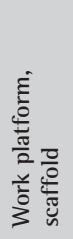 & $\begin{array}{l}\frac{\bar{\nu}}{\frac{0}{0}} \\
\frac{\pi}{0} \\
\frac{\pi}{2} \\
\hbar\end{array}$ & 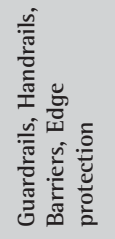 & 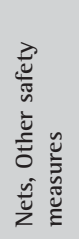 & 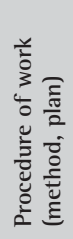 & 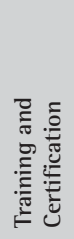 & 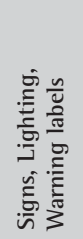 & 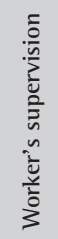 & 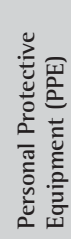 \\
\hline 37 & NA & A & & & & & NA & 0 & & & $\mathrm{~A}$ \\
\hline 38 & NA & & & & 0 & & 0 & & & & \\
\hline 39 & & & NA & A & & & 0 & & & A & \\
\hline 40 & NA & & & & 0 & & A & & 0 & & \\
\hline 41 & & & NA & & 0 & & & & & 0 & \\
\hline 42 & 0 & & 0 & & & & 0 & & & 0 & \\
\hline 43 & & A & NA & & & & & & A & & \\
\hline 44 & & & & & & & 0 & 0 & & 0 & \\
\hline 45 & A & & A & & 0 & A & NA & & & & A \\
\hline 46 & A & & & & 0 & & & & A & & \\
\hline 47 & NA & & & & & A & $\mathrm{A}$ & 0 & & A & A \\
\hline 48 & & & A & & & & NA & A & & NA & \\
\hline 49 & & 0 & 0 & & 0 & & & 0 & & & 0 \\
\hline 50 & & & & & & & & & & & \\
\hline 51 & & & 0 & & & & A & & & & \\
\hline 52 & & & 0 & & & & A & & & A & \\
\hline 53 & NA & & & & NA & & & & A & & \\
\hline 54 & & & NA & & & & 0 & 0 & & A & \\
\hline 55 & & & & & & & A & 0 & & 0 & \\
\hline 56 & & & & NA & & & & 0 & & & \\
\hline 57 & & & NA & & & & NA & & & NA & A \\
\hline 58 & 0 & & A & & A & A & NA & & & & 0 \\
\hline 59 & & & NA & & NA & & NA & & & & A \\
\hline 60 & 0 & & A & & A & $\mathrm{A}$ & A & 0 & & & 0 \\
\hline 61 & NA & & & & & & & 0 & & 0 & \\
\hline 62 & NA & & & & 0 & & NA & & 0 & & \\
\hline 63 & & & & & 0 & & A & 0 & & 0 & 0 \\
\hline 64 & NA & & 0 & & 0 & $\mathrm{~A}$ & A & & & & A \\
\hline 65 & 0 & & A & & A & A & A & & & & 0 \\
\hline 66 & A & & & & 0 & & A & & & & A \\
\hline 67 & NA & & & & & A & NA & & & 0 & A \\
\hline 68 & & A & & & 0 & & & & & & 0 \\
\hline 69 & 0 & & & & A & & NA & & & & A \\
\hline 70 & NA & & & & 0 & & NA & & & & A \\
\hline 71 & & & NA & & A & $\mathrm{A}$ & A & & & & 0 \\
\hline 72 & 0 & & 0 & & 0 & A & A & 0 & & & 0 \\
\hline 73 & A & & A & & A & A & NA & & & NA & $\mathrm{A}$ \\
\hline 74 & NA & & NA & & $\mathrm{NA}$ & & NA & & & NA & A \\
\hline 75 & 0 & & A & & A & $\mathrm{A}$ & A & 0 & & & 0 \\
\hline 76 & A & & NA & & NA & A & $\mathrm{A}$ & & & & A \\
\hline 77 & A & & 0 & & A & 0 & A & & & & 0 \\
\hline 78 & NA & & 0 & & 0 & A & NA & & & 0 & 0 \\
\hline 79 & & & NA & & & & NA & 0 & & NA & \\
\hline 80 & A & & A & & A & A & NA & & & & 0 \\
\hline 81 & & & & & & & NA & 0 & & & \\
\hline 82 & A & & A & & 0 & 0 & NA & & & 0 & A \\
\hline 83 & & & NA & & NA & & & & & & \\
\hline 84 & & & NA & & NA & & & & & & \\
\hline 85 & & & & & $\mathrm{NA}$ & & NA & & & & \\
\hline 86 & NA & & A & & 0 & A & A & NA & & & A \\
\hline 87 & 0 & & A & & $\mathrm{A}$ & A & 0 & & & 0 & 0 \\
\hline 88 & A & & A & & A & A & NA & & & & 0 \\
\hline 89 & NA & & & & 0 & $\mathrm{~A}$ & NA & & & & $\mathrm{A}$ \\
\hline 90 & NA & & A & & 0 & $\mathrm{~A}$ & NA & & & 0 & A \\
\hline 91 & & & & & 0 & & & & & & \\
\hline 92 & & & & & & & NA & & & 0 & \\
\hline 93 & A & & NA & & A & $\mathrm{A}$ & $\mathrm{A}$ & & & & 0 \\
\hline
\end{tabular}


Table 3A. Continued...

\begin{tabular}{|c|c|c|c|c|c|c|c|c|c|c|c|}
\hline $\mathrm{Nr}$ & 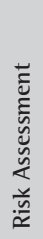 & 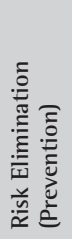 & 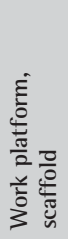 & $\frac{\frac{\bar{t}}{0}}{\frac{\pi}{0}} \frac{0}{\frac{\pi}{n}}$ & 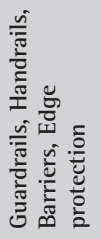 & 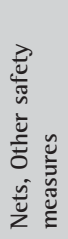 & 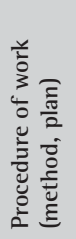 & 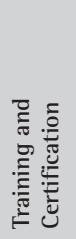 & 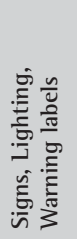 & 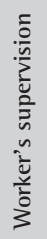 & 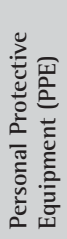 \\
\hline 94 & & & & & & & NA & & & & A \\
\hline 95 & $A$ & & $A$ & & $A$ & $A$ & $A$ & & & & 0 \\
\hline 96 & & & NA & & & & NA & & & 0 & $A$ \\
\hline 97 & & & & & & & NA & & & & 0 \\
\hline 98 & A & & & & NA & & & & A & & \\
\hline 99 & & & & & NA & & $A$ & & & & 0 \\
\hline 100 & & & $\mathrm{NA}$ & & NA & & NA & & & & 0 \\
\hline \multicolumn{12}{|l|}{101} \\
\hline 102 & & & & & & & A & A & & & NA \\
\hline 103 & & & A & & & & NA & & & 0 & $A$ \\
\hline 104 & & & NA & & & & & & & & NA \\
\hline 105 & & & NA & & & & & & & & \\
\hline 106 & A & & NA & & A & A & NA & & & A & NA \\
\hline 107 & & & & & 0 & & & & & & 0 \\
\hline 108 & & & & & 0 & & A & A & 0 & A & \\
\hline 109 & & & NA & & & & NA & & & & 0 \\
\hline 110 & A & & & & & A & NA & NA & & & A \\
\hline 111 & & & NA & & & & NA & & & & \\
\hline 112 & A & & NA & & A & 0 & NA & 0 & & & 0 \\
\hline 113 & & & NA & & & & NA & & & & \\
\hline 114 & A & & & & NA & & NA & & & & \\
\hline
\end{tabular}

Table 4A. Included articles, illustration of accidents which were related to most common falling places.

\begin{tabular}{|c|c|c|c|c|c|c|c|}
\hline $\mathrm{Nr}$ & $\begin{array}{l}\text { Scaffold/ } \\
\text { Platform }\end{array}$ & Roof & $\begin{array}{c}\text { Floor/ Wall/ } \\
\text { Staircase } \\
\text { Collapse }\end{array}$ & $\begin{array}{c}\text { Stairwell/ } \\
\text { Trapdoor/ Lift } \\
\text { well/ Glass panel in } \\
\text { construction }\end{array}$ & $\begin{array}{c}\text { Ladder/ } \\
\text { Stepladder }\end{array}$ & $\begin{array}{c}\text { Lifting } \\
\text { (forklift...) }\end{array}$ & Other \\
\hline 1 & & & & & & & 1 \\
\hline 2 & & & & & & & 1 \\
\hline 3 & & & & & & & 1 \\
\hline 4 & & & & & 1 & & \\
\hline 5 & & & & & 1 & & \\
\hline 6 & & & & & 1 & & \\
\hline 7 & 1 & & & & & & \\
\hline 8 & & & & & 1 & & \\
\hline 9 & & & & & & & 1 \\
\hline 10 & & & & & & & 1 \\
\hline 11 & & & & & & & 1 \\
\hline 12 & & & & & & & 1 \\
\hline 13 & & & & & & & 1 \\
\hline 14 & & & & & & & 1 \\
\hline 15 & & & & 1 & & & \\
\hline 16 & 1 & & & & & & \\
\hline 17 & 1 & & & 1 & & & \\
\hline 18 & 1 & & & 1 & & & \\
\hline 19 & & & & 1 & & & \\
\hline 20 & & 1 & & & & & \\
\hline 21 & & 1 & & & & & \\
\hline 22 & & & & 1 & & & \\
\hline 23 & & & & & & & 1 \\
\hline 24 & & & & & & & 1 \\
\hline
\end{tabular}


Table 4A. Continued...

\begin{tabular}{|c|c|c|c|c|c|c|c|}
\hline $\mathrm{Nr}$ & $\begin{array}{l}\text { Scaffold/ } \\
\text { Platform }\end{array}$ & Roof & $\begin{array}{c}\text { Floor/ Wall/ } \\
\text { Staircase } \\
\text { Collapse }\end{array}$ & $\begin{array}{c}\text { Stairwell/ } \\
\text { Trapdoor/ Lift } \\
\text { well/ Glass panel in } \\
\text { construction }\end{array}$ & $\begin{array}{c}\text { Ladder/ } \\
\text { Stepladder }\end{array}$ & $\begin{array}{c}\text { Lifting } \\
\text { (forklift...) }\end{array}$ & Other \\
\hline 25 & & & & 1 & & & \\
\hline 26 & 1 & & & & & & \\
\hline 27 & & & & & & 1 & \\
\hline 28 & & & & & 1 & & \\
\hline 29 & & & & & & 1 & \\
\hline 30 & 1 & & & & & & \\
\hline 31 & & & & & & & 1 \\
\hline 32 & & & & & & & 1 \\
\hline 33 & & & & & & & 1 \\
\hline 34 & & & 1 & & & & \\
\hline 35 & & & & & & & 1 \\
\hline 36 & & & & & & & 1 \\
\hline 37 & & & & & & & 1 \\
\hline 38 & & & & & & & 1 \\
\hline 39 & & & & & & 1 & \\
\hline 40 & & 1 & & & & & \\
\hline 41 & 1 & & & & & & \\
\hline 42 & 1 & & & & & & \\
\hline 43 & & & 1 & & & & \\
\hline 44 & & & & & & & 1 \\
\hline 45 & & & & 1 & & & \\
\hline 46 & & & & & & & 1 \\
\hline 47 & & & & & & & 1 \\
\hline 48 & 1 & & & & & & \\
\hline 49 & & & & 1 & & & \\
\hline 50 & & & & & & & 1 \\
\hline 51 & & & & & & & 1 \\
\hline 52 & & & & & & 1 & \\
\hline 53 & & & & & & & 1 \\
\hline 54 & 1 & & & & & & \\
\hline 55 & & & & & & 1 & \\
\hline 56 & & & & & 1 & & \\
\hline 57 & 1 & & & & & & \\
\hline 58 & & 1 & & & & & \\
\hline 59 & 1 & & & & & & \\
\hline 60 & & 1 & & & & & \\
\hline 61 & & & & & & & 1 \\
\hline 62 & & & & & & & 1 \\
\hline 63 & & 1 & & & & & \\
\hline 64 & & 1 & & & & & \\
\hline 65 & & 1 & & & & & \\
\hline 66 & 1 & & & & & & \\
\hline 67 & & & & & & 1 & \\
\hline 68 & & & & 1 & & & \\
\hline 69 & & 1 & & & & & \\
\hline 70 & & 1 & & & & & \\
\hline 71 & 1 & & & & & & \\
\hline 72 & & 1 & & & & & \\
\hline 73 & & 1 & & & & & \\
\hline 74 & 1 & & & & & & \\
\hline 75 & & 1 & & & & & \\
\hline 76 & 1 & & & & & & \\
\hline 77 & & 1 & & & & & \\
\hline
\end{tabular}


Table 4A. Continued...

\begin{tabular}{|c|c|c|c|c|c|c|c|}
\hline $\mathrm{Nr}$ & $\begin{array}{l}\text { Scaffold/ } \\
\text { Platform }\end{array}$ & Roof & $\begin{array}{l}\text { Floor/ Wall/ } \\
\text { Staircase } \\
\text { Collapse }\end{array}$ & $\begin{array}{c}\text { Stairwell/ } \\
\text { Trapdoor/ Lift } \\
\text { well/ Glass panel in } \\
\text { construction }\end{array}$ & $\begin{array}{l}\text { Ladder/ } \\
\text { Stepladder }\end{array}$ & $\begin{array}{c}\text { Lifting } \\
\text { (forklift...) }\end{array}$ & Other \\
\hline 78 & & 1 & & & & & \\
\hline 79 & & & & & & 1 & \\
\hline 80 & & 1 & & & & & \\
\hline 81 & 1 & & & & & 1 & \\
\hline 82 & & 1 & & & & & \\
\hline 83 & & 1 & & & & 1 & \\
\hline 84 & & & & & & 1 & \\
\hline 85 & & & & & & & 1 \\
\hline 86 & & 1 & & & & & \\
\hline 87 & & 1 & & & & & \\
\hline 88 & & 1 & & & & & \\
\hline 89 & & 1 & & & 1 & & \\
\hline 90 & & 1 & & & & & \\
\hline 91 & & & & 1 & & & \\
\hline 92 & & & & & & & 1 \\
\hline 93 & & 1 & & & & & \\
\hline 94 & & 1 & & & & & \\
\hline 95 & & 1 & & & & & \\
\hline 96 & 1 & & & 1 & & & \\
\hline 97 & & & & & & & 1 \\
\hline 98 & & & & & & & 1 \\
\hline 99 & & & & & & & 1 \\
\hline 100 & & & & 1 & & & \\
\hline 101 & & & & & & & 1 \\
\hline 102 & & & & & & & 1 \\
\hline 103 & 1 & & & & & & \\
\hline 104 & & & & & & & 1 \\
\hline 105 & & & & & & & 1 \\
\hline 106 & 1 & & & & & & \\
\hline 107 & & & 1 & & & & \\
\hline 108 & & & & 1 & & & \\
\hline 109 & 1 & & & & & & \\
\hline 110 & 1 & & & & 1 & & \\
\hline 111 & 1 & & & & & & \\
\hline 112 & & 1 & & & & & \\
\hline 113 & & & 1 & & & & \\
\hline 114 & & & & 1 & & & \\
\hline
\end{tabular}

